\title{
¡Que no baje el telón! Recupero e valorizzazione della Facultad de Arte Teatral dell'Universidad de las Artes de La Habana
}

\author{
Alessandro Merlo
}

Abstract

Le Scuole d'Arte di Cubanacán a La Habana, oggi Universidad de las Artes (ISA), rappresentano il primo grande progetto post Rivoluzione voluto da Fidel Castro e Ernesto Che Guevara nell'ambito della formazione. Le cinque iniziali Scuole (musica, danza, balletto, arti drammatiche e arti plastiche) oltre a essere note alla comunità scientifica per la qualità dell'insegnamento, caratterizzato da inediti itinerari di sperimentazione creativa, sono conosciute per aver avuto inizialmente sede in edifici dallo straordinario valore architettonico e paesaggistico eretti all'interno del grande parco dell'ex Country Club. Nel corso dei decenni, per ragioni il cui approfondimento esula dallo scopo di questo contributo, tre di tali manufatti (musica, balletto e arti drammatiche) sono stati progressivamente abbandonati e versano oggi in uno stato di deprecabile degrado.

Nel settembre del 2019, grazie all'interesse del governo italiano, ha preso avvio il progetto di cooperazione internazionale denominato iQue no baje el telón!, diretto al recupero architettonico e funzionale della sede originaria della Facultad de Arte Teatral (FAT) progettata dall'architetto Roberto Gottardi al principio degli anni ' 60 del $X X$ secolo; auspicabilmente l'inizio di un percorso sostenibile e partecipato per la rivalorizzazione dell'intero complesso dell'ISA (monumento nazionale dal 20।0) [I]. Nel programma dei lavori la documentazione morfometrica e cromatica della FAT riveste un ruolo chiave, costituendo la necessaria premessa al progetto di restauro, conservazione e gestione del bene.

Parole chiave

Facultad de Arte Teatral de La Habana, Universidad de las Artes (ISA), cultural heritage, cooperazione internazionale, rilievo digitale.

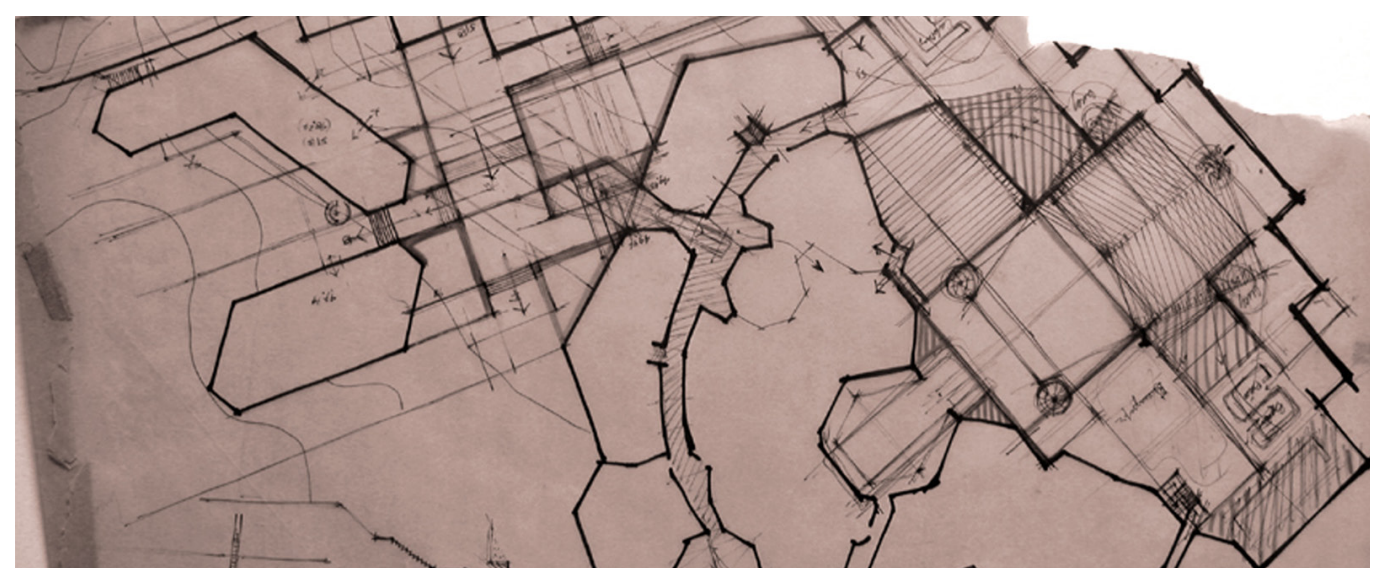




\section{Dalla Escuela Nacional de Artes all'Universidad de las Artes}

Tra il 1960 e il 1965 vennero realizzate cinque Scuole (per un totale di $51.000 \mathrm{~m}^{2}$ ) nel parco dell'ex Country Club de la Habana $\left(560.000 \mathrm{~m}^{2}\right.$ tra il fondovalle del fiume Quibú e i rilievi attigui) che, da luogo esclusivo della élite cubana, divenne uno spazio dove i giovani di tutte le classi sociali potevano apprendere i rudimenti delle Arti (fig. I).

II progetto fu affidato all'architetto cubano Ricardo Porro Hidalgo e agli architetti italiani Roberto Gottardi e Vittorio Garatti, che poterono operare senza limiti di budget. Due gli obiettivi principali: integrare gli edifici con il contesto naturale del Cubanacán (dal toponimo dell'area) secondo gli insegnamenti della scuola rogersiana e utilizzare materiali di produzione nazionale, in particolare il laterizio, con il fine di ridurre l'importazione di acciaio e cemento, resi costosi dall'embargo statunitense [2].

Nacquero così la Scuola di Arti Plastiche e la Scuola di Danza di Porro Hidalgo, la Scuola di Balletto e la Scuola di Musica di Garatti e la Scuola di Teatro di Gottardi (fig. 2). Le fasi di progettazione furono, forse inconsapevolmente, 'partecipate' poiché tecnici, maestranze, professori, studenti e cittadini, facilitati da un contesto culturale senza eguali, presero parte al processo ideativo.

Gli edifici della Escuela Nacional de Artes furono inaugurati nel 1965 (l'istituzione dell'ENA risaliva al 1962), anche se alcune parti del complesso architettonico non erano state completate per mancanza di finanziamenti dovuta alla sopraggiunta 'crisi dei missili'. La Scuola di Danza e quella di Balletto, pur terminate, non furono mai usate come tali, mentre la Scuola di Musica, quella di Teatro e quella delle Arti Plastiche erano ultimate per non più del 50\%. L'organizzazione della didattica dovette pertanto adattarsi a ciò che era stato costruito, anche se pensato con funzioni diverse.

Nel decennio successivo venne in parte riformato l'insegnamento delle arti e parallelamente al livello pre-universitario gestito dall'ENA furono avviati i primi corsi universitari erogati dall'ISA (Instituto Superior de Arte oggi Universidad de las Artes) [3].

L'Universidad de las Artes ospita le Facoltà di Música, Arte Danzarío, Arte Teatral, Artes Visuales, Artes de la Conservación del Patrimonio Cultural y Restauración e Arte de los Medios de Comunicación Audiovisual, e costituisce un unicum nel paese per avere i sei percorsi di studio racchiusi in un solo campus.

Nel tempo le condizioni ambientali, le esondazioni del fiume Quibú che attraversa l'area, i materiali da costruzione utilizzati, la scarsa se non assente manutenzione hanno portato al deterioramento degli edifici rendendone alcuni inagibili.

All'inizio del $X X \mid$ secolo il governo cubano affrontò per la prima volta il problema del restauro e completamento degli edifici dell'ISA, tanto che venne presa la decisione di fi-

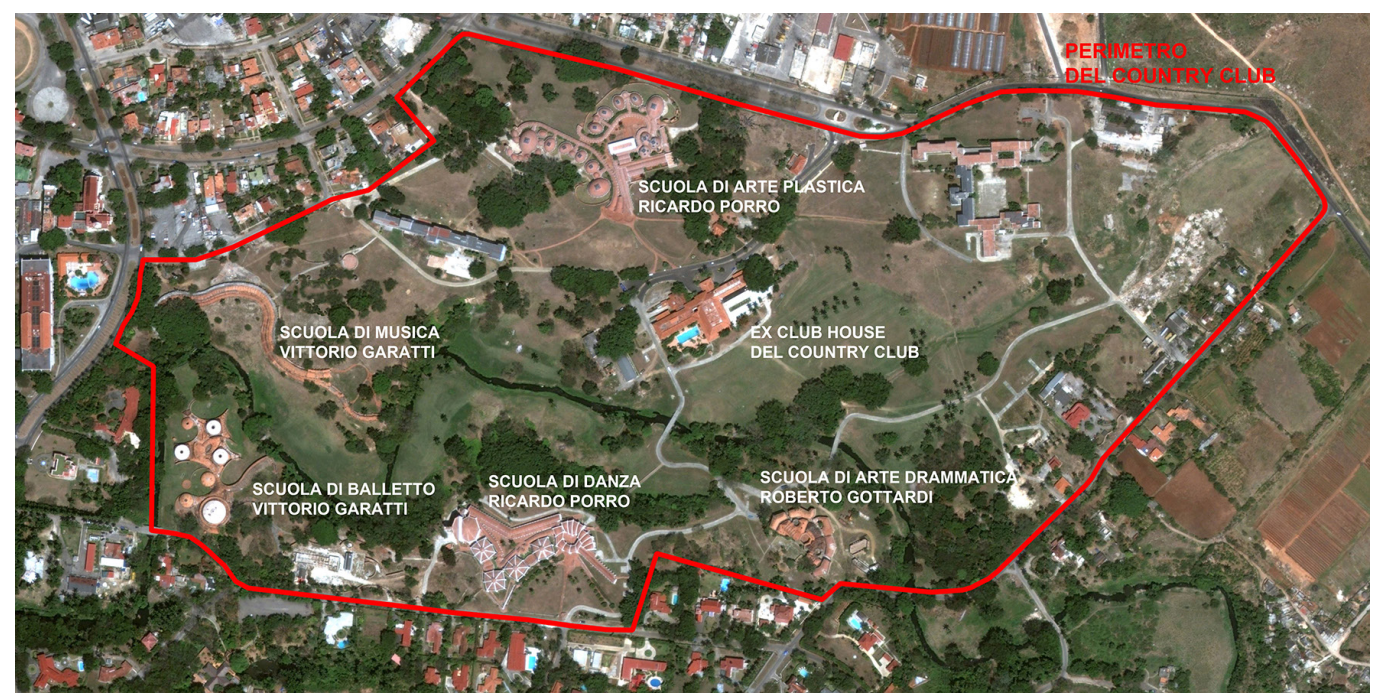




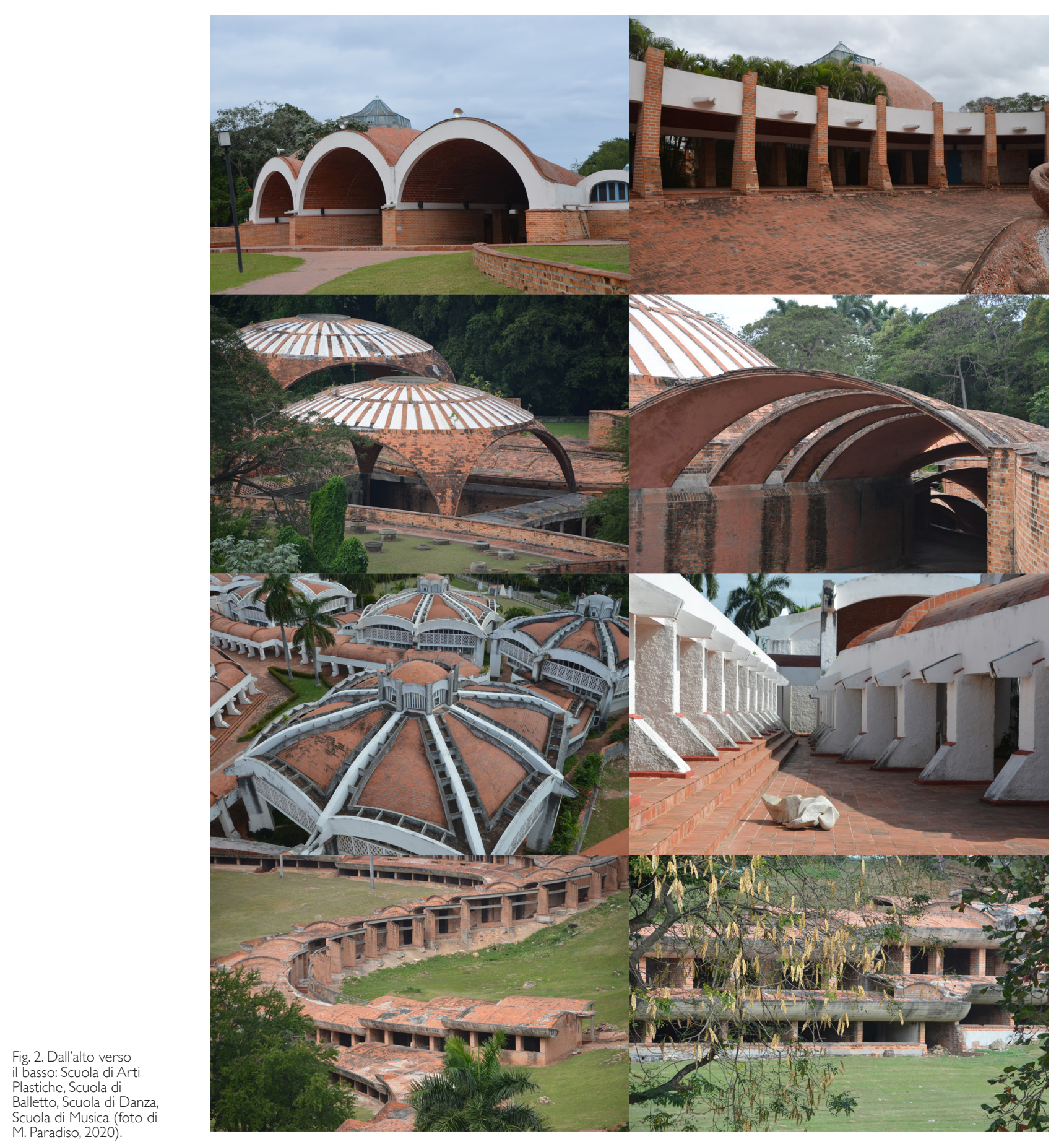


nanziare i lavori di riabilitazione del complesso. A tale fine venne creato il Centro per gli Investimenti del Ministerio de Cultura de la República de Cuba (MINCULT), coordinato dal Consiglio di Stato, con il compito di strutturare il programma di intervento nel più breve tempo possibile. Porro Hidalgo, Gottardi e Garatti vennero incaricati del progetto anche se nei fatti i lavori furono condotti da tecnici del Governo. A partire dal 1999 vennero svolte alcune indagini volte a valutare il deterioramento degli edifici e a definire le nuove esigenze funzionali; nel 2000 presero avvio i lavori sulle scuole di Porro, sotto la direzione dell'architetto Universo Garcia Lorenzo (progettista principale dell'Impresa Emproy-2 afferente al MICONS), che si conclusero nel 2010 [4].

A inizio 2007 Garcia Lorenzo aveva predisposto assieme a Gottardi una prima proposta di intervento sulla Escuela de Teatro; si trattava di restaurare le parti già edificate e realizzare quelle mancanti secondo il progetto originario, oltre a prevedere degli ampliamenti per meglio rispondere alle mutate necessità didattiche (fig. 3). Le successive fasi di diagnostica misero in evidenza una situazione di degrado avanzato soprattutto nei materiali costituenti le murature in elevato e le volte catalane. I lavori iniziarono tre anni più tardi, ma si bloccarono dopo pochi mesi per mancanza di fondi.

II 29 ottobre 2015, durante una visita ufficiale a Cuba dell'allora Presidente del Consiglio dei Ministri della Repubblica Italiana Matteo Renzi, vennero gettate le basi per un nuovo progetto di restauro delle Scuole d'Arte. Individuata nella FAT la struttura più indicata, l'allora Ministro della Cultura della Repubblica di Cuba fece formale richiesta di fondi all'Italia attraverso la Cooperazione Internazionale allo Sviluppo. Dopo tre anni di intensa opera di sensibilizzazione, finalizzata a mettere in atto meccanismi di coordinamento trasversale tra tutti gli attori interessati al progetto, il I 5 febbraio del 2019 è stato firmato l'Accordo intergovernativo Italia-Cuba che ha dato il via libera al Progetto iQue no baje el telón! Conservación, Gestión y Puesta en Valor de la Facultad de Arte Teatral del ISA: Rehabilitación y Difusión, Capacitación y Monitoreo.

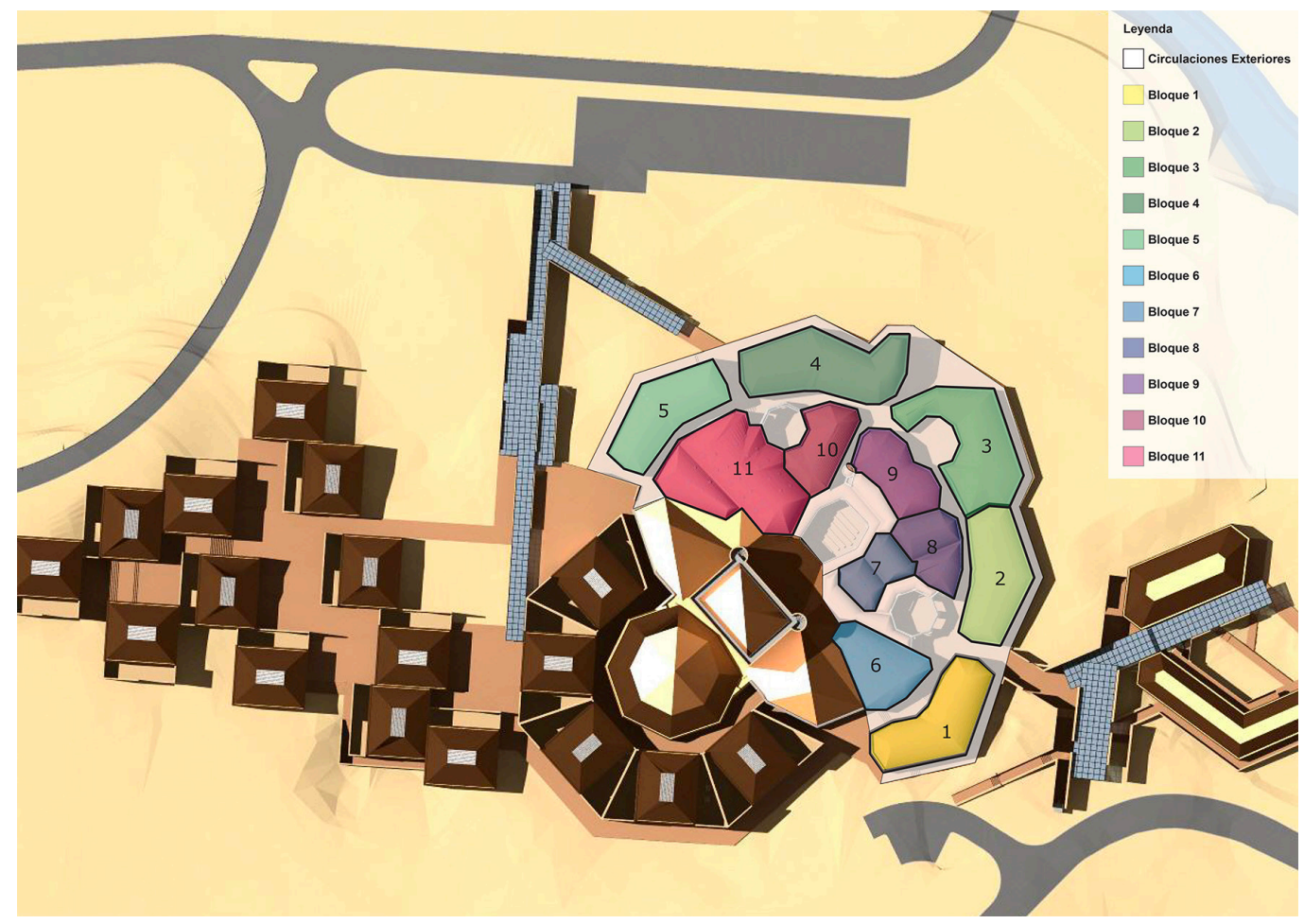




\section{Il progetto di cooperazione internazionale ¡Que no baje el telón!}

Il progetto di cooperazione internazionale [5], presentato all'Agenzia per la Cooperazione e lo Sviluppo (AICS) della Repubblica Italiana dal MINCULT, ha come principali partner il Dipartimento di Architettura (DIDA) dell'Università degli Studi di Firenze e I'ISA. L'obiettivo principale è quello di rafforzare la Facultad de Arte Teatral attraverso tre distinte azioni: riattivare la sua sede originale, aggiornare i piani di studio e ampliare la dimensione internazionale. Data la complessità e la portata di tali azioni il Progetto è stato scisso in due componenti: la componente A (Rehabilitación y Difusión) ha come obiettivo specifico il restauro, consolidamento e rifunzionalizzazione della sede originaria della FAT, oltre che alla disseminazione dei risultati conseguiti; la componente B (Capacitación y Monitoreo) si propone di contribuire al capacity building di tutti i soggetti che operano nel campo della documentazione, conservazione, gestione e valorizzazione del patrimonio culturale - in particolare di quello materiale delle architetture dell'ISA e del Municipio Playa e di quello immateriale delle arti teatrali - e al monitoraggio di tutti gli interventi previsti nel Documento di Progetto, al fine di garantirne la corretta esecuzione.

La prima componente consentirà non solo di conservare e tutelare un bene culturale di indiscusso valore storico-architettonico, conosciuto e considerato tale a livello mondiale, ma anche di migliorare e incrementare le attività formative della Facoltà. Una volta che l'edificio sarà nuovamente a regime potranno infatti essere attivate nuove iniziative tese a sensibilizzare e avvicinare all'arte e alla cultura le comunità locali, predisposti dei progetti congiunti con altre realtà accademiche nazionali e avviate delle nuove collaborazioni in ambito internazionale.

Attraverso la seconda componente si intende invece colmare alcune carenze specifiche nell'ambito del rilievo digitale, del restauro e del consolidamento degli edifici monumentali, mediante l'attivazione di corsi di aggiornamento professionale [6] diretti sia al personale

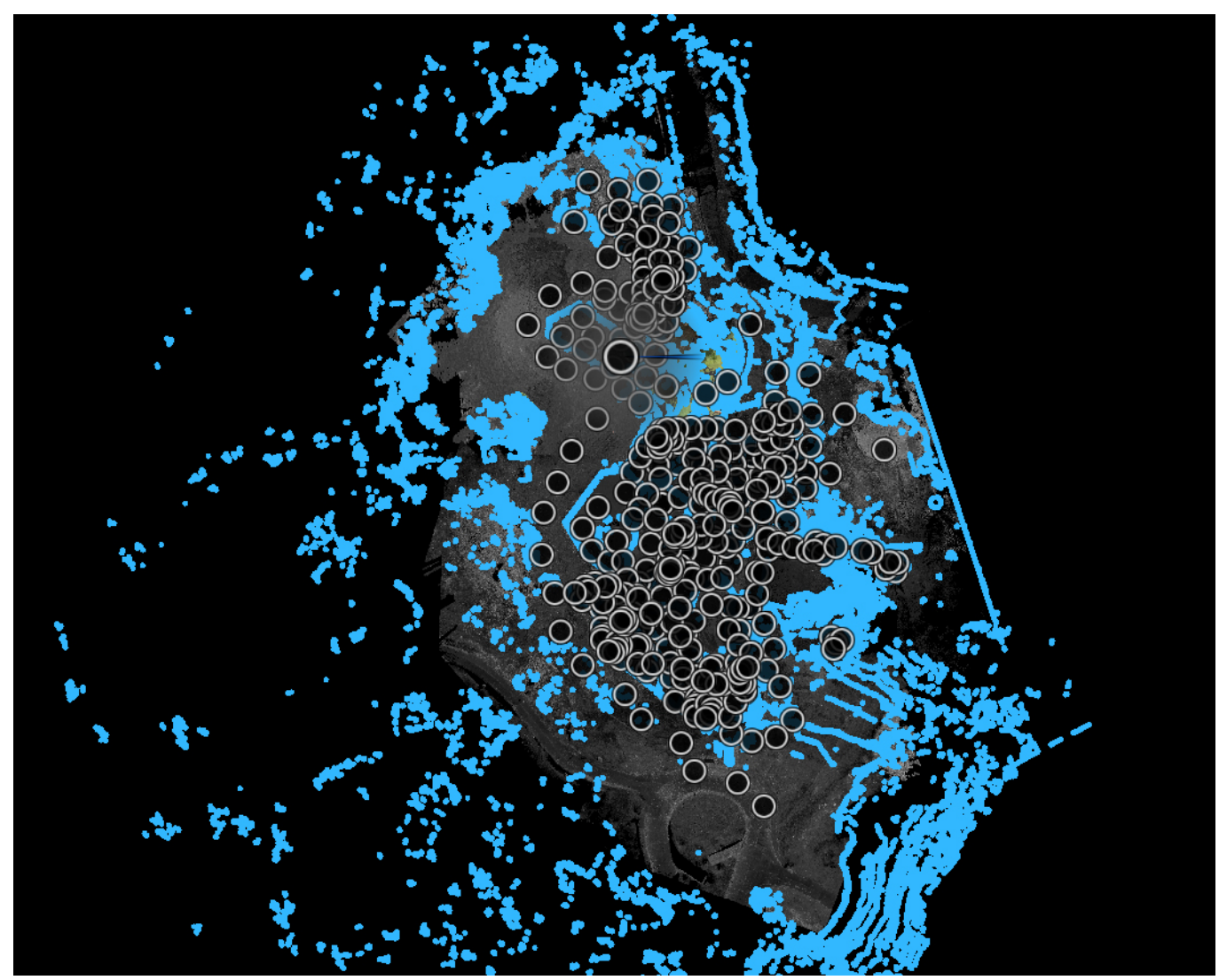


Fig. 5. Processo di realizzazione del modello poligonale attraverso software Agisoft MetashapePro (CHMLab).

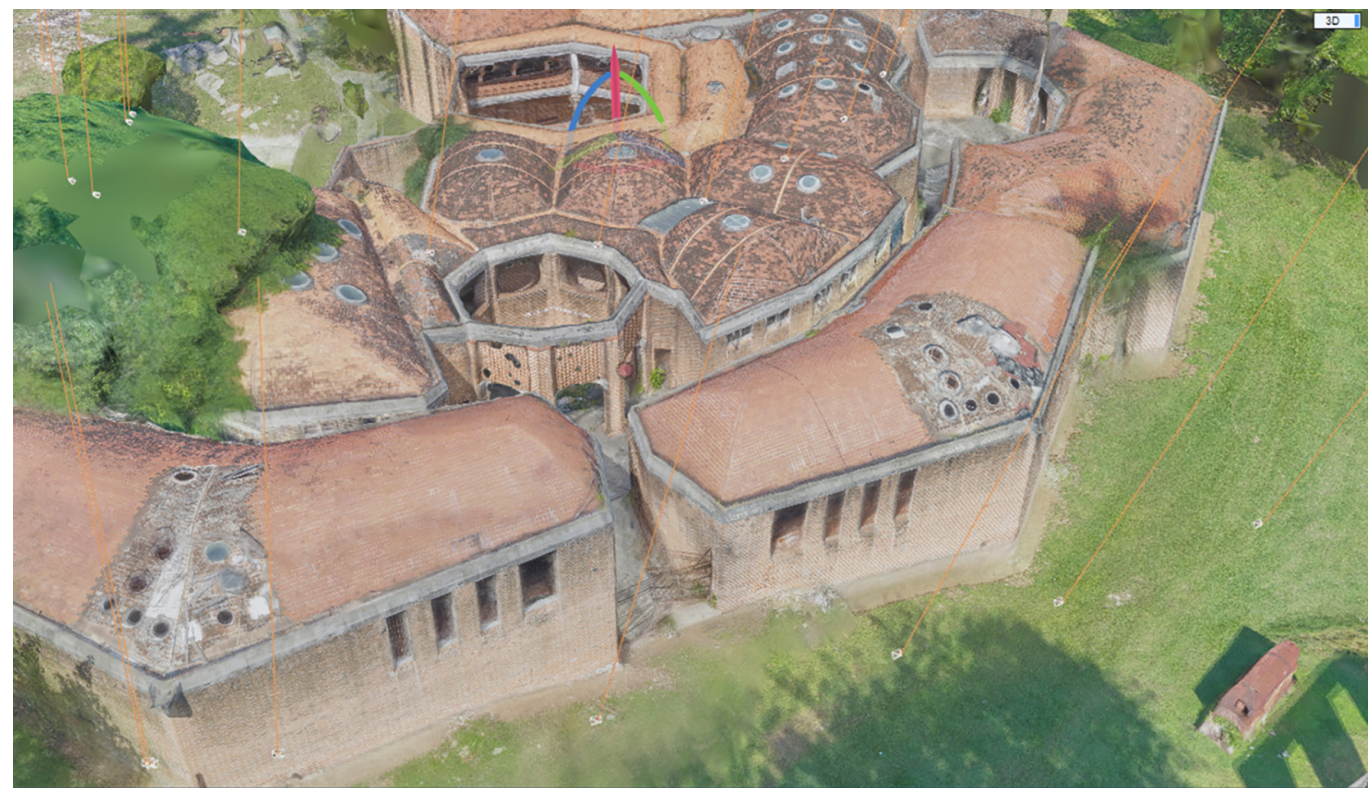

impiegato presso i ministeri che si occupano della conservazione del patrimonio architettonico sia a professionisti e maestranze del settore edile, oltre che agli studenti dell'ISA e delle Facoltà di Ingegneria e di Architettura presenti nel paese. Parallelamente a tali corsi, che contribuiscono a formare una comune base di conoscenze tra il personale locale e quello italiano, il DIDA ha attivato un'azione di monitoraggio continuo del processo progettuale e costruttivo, finalizzato ad assicurare l'effettiva realizzazione a regola d'arte delle opere.

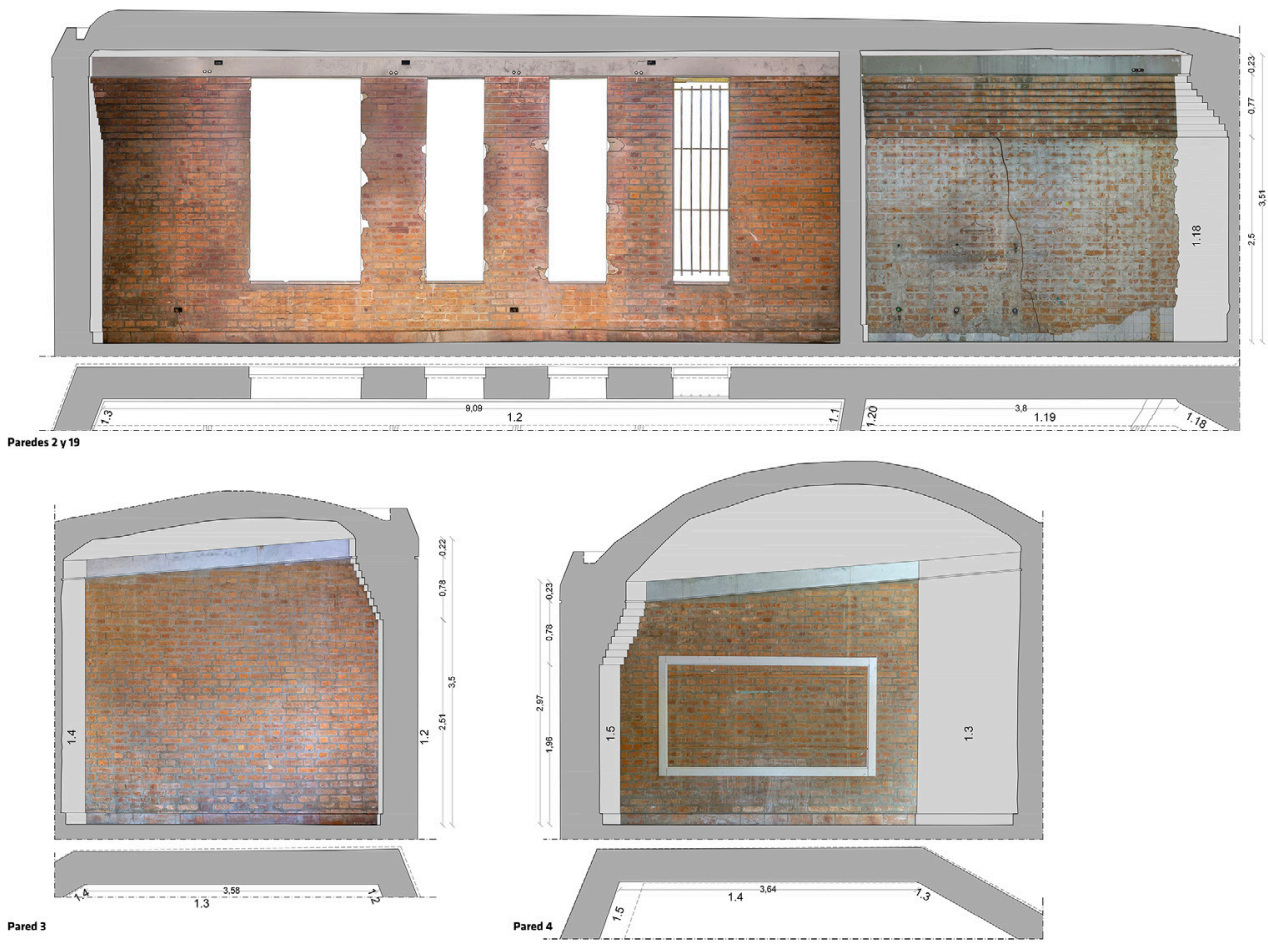

Pared 3
Fig. 6. Esempio di fotopiano di una delle pareti de 3, 4, 19, CHMLab). 
Fig. 7. Pianta di progetto, 1962, arch. R. Gottard (Archivio Oficina de Historiador de La Habana, riferimento file: AHC-4549. II. Escuela de Arte Dramatico.pdf).

Fig. 8. Elaborazione dei rilievi del 2000-2002 2010,2017 e 2020 (A. Merlo).
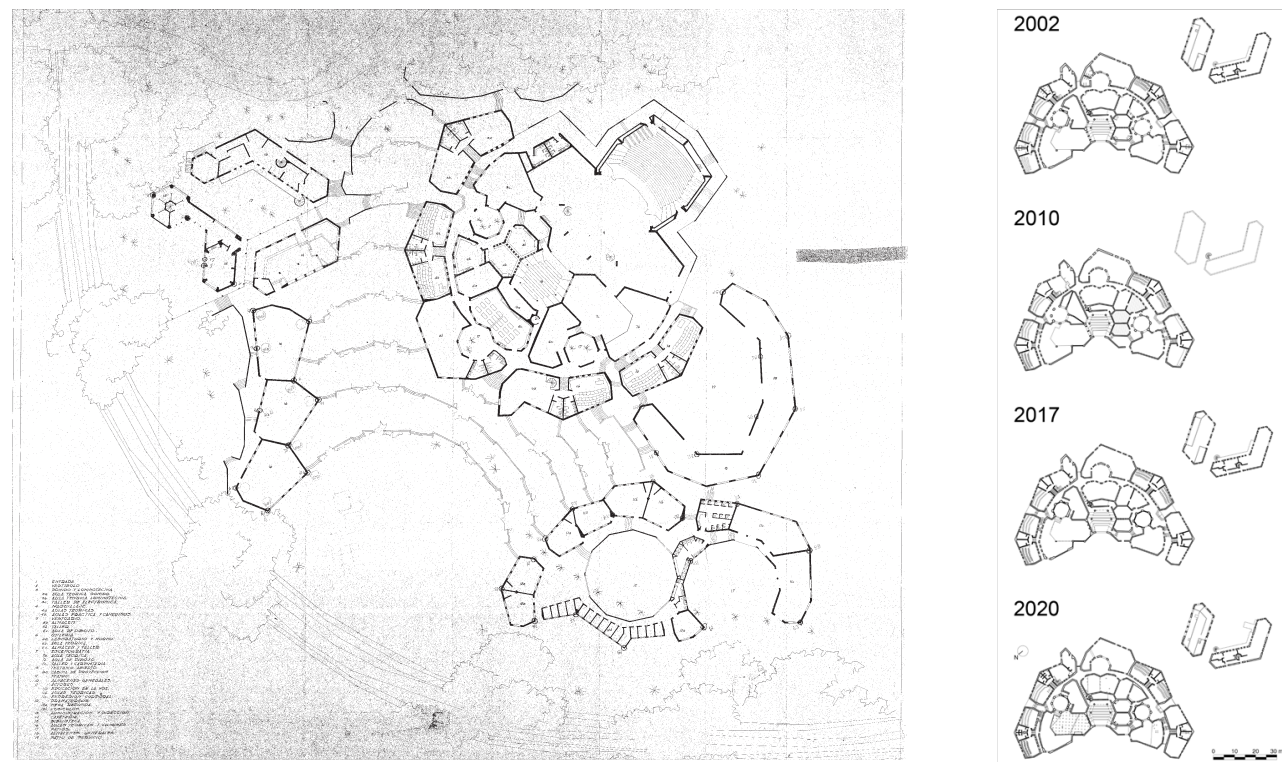

\section{La documentazione morfometrica e cromatica della FAT}

Il rilevamento del manufatto è stato condotto in parallelo al primo corso di Aggiornamento Professionale [7] Levantamiento digital y modelación 3D, offerto da UNIFI e svoltosi dal 14 ottobre al $1{ }^{\circ}$ novembre 2019 presso I'ISA. Le operazioni di documentazione digitale sono state realizzate mediante quattro unità scanner laser (Leica ScanStation P40, Leica ScanStation CIO, Z+F Imager® 50 I 0, Leica BLK360 Imaging LS) per quanto concerne gli aspetti morfometrici e cinque camere fotografiche (quattro fotocamere Sony Alpha 6000 con obiettivo Sony E PZ I 8- I05mm per la presa da terra e una Hasselblad LID-20c per la presa aerea da drone) per quelli cromatici [8]. I dati grezzi elaborati attraverso software
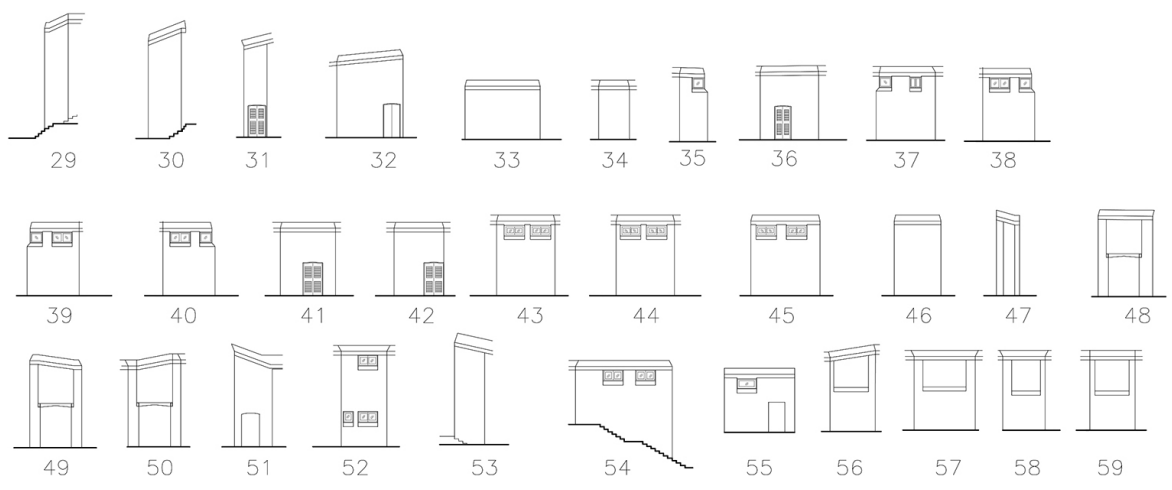
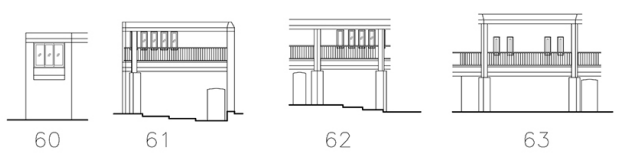

63

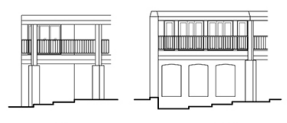

64

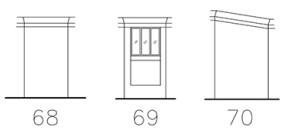

62
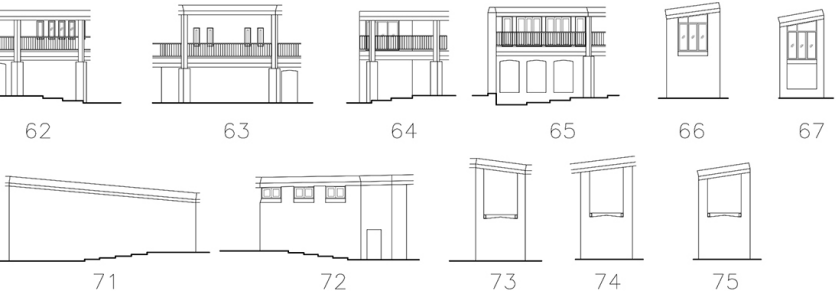

66

67
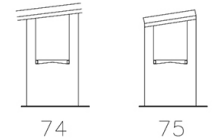
Fig. 10. Raffronto tra T'elaborato di progetto del 1962 e il rilievo de 2020 in colore verde
(A. Merlo).

Fig. 1 1. Raffronto tra il rilievo del 2020 in verde e il rilievo del 2017 in rosso (A. Merlo).
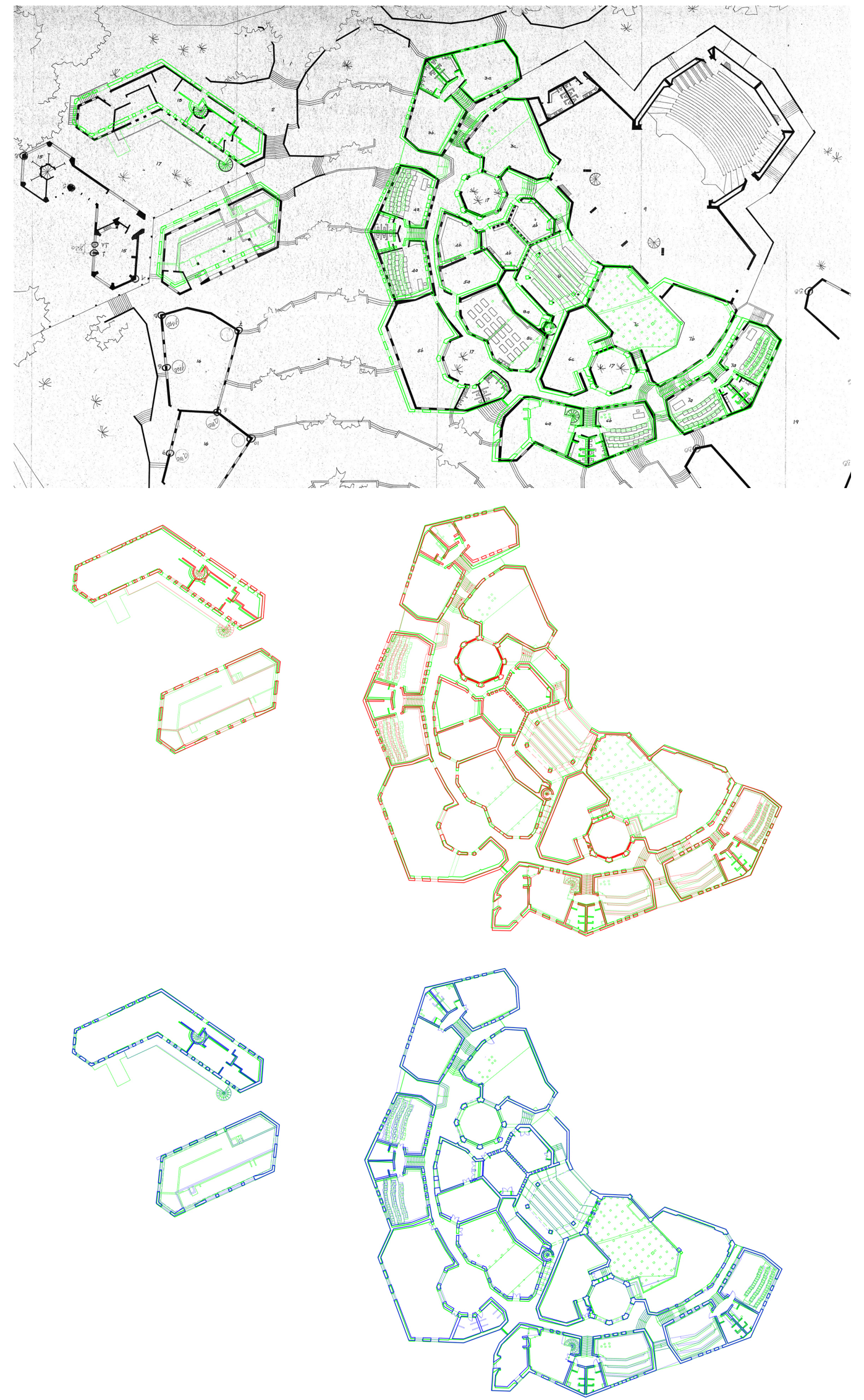
dedicati (Autocad Recap, Agisoft MetashapePro e Capturing Reality Reality Capture) hanno consentito di desumere un unico modello 3D a nuvola di punti $\left(247 \mid \times 10^{6}\right.$ punti fig. 4) [9] e le texture del colore apparente relative a pareti, coperture e pavimentazioni (fig. 5) [10].

Dal modello 3D sono state desunte piante e sezioni dell'intero complesso, utilizzate inizialmente per verificare la bontà dei rilievi pregressi e integrarli là dove necessario. I fotopiani in scala l:20 (fig. 6) relativi ai I 4 corpi di fabbrica di cui è formata la FAT hanno consentito invece di rappresentare con il dovuto grado di dettaglio le patologie relative ai materiali e alle strutture (oggetto del secondo corso).

Di particolare interesse, in questa fase iniziale del Progetto, è risultato lo studio comparativo tra il materiale grafico raffigurante il progetto architettonico del 1962 [I I ], i rilievi realizzati tra il 2000 e il 2002 e nel 2017 in vista dei due principali interventi di restauro [12] e, infine, il rilievo digitale del 2020.

L'elaborato datato 1962 (fig. 7) mostra in proiezione ortografica la sezione orizzontale di progetto realizzata a più quote riferite all'ultimo piano di calpestio di ciascun blocco (i comparti I, 2, 3, 7, 8, 9 e I 0 presentano un solo livello, i comparti 4, 5, 6 ne hanno due e il blocco I I è un doppio volume in parte suddiviso da un solaio intermedio). Data la peculiarità di tale elaborato, per i rilievi del 2000-2002, 2017 e 2020 è stato necessario redigere ex novo una versione analoga che, disponendo degli elaborati CAD, è stata realizzata in tempi brevi e con un margine di errore pressoché nullo (fig. 8).

II rilievo di inizio XXI secolo, frutto di una estesa campagna topografica realizzata dal Ministerio de la Construcción (MICONS) attraverso il Departamento de Topografía (Jefe de Departamento Miguel M. De Ayala), rappresenta esaustivamente la FAT mediante 3 piante, 32 sezioni e 75 prospetti, in scala dall' l:50 all' l:500 (fig. 9) [I3].

Nel 2017, una volta affidato l'incarico del progetto di rehabilitación all'impresa Atrio del MINCULT, i tecnici incaricati (Proyectista Principal Arch. Isabel Marilyn Mederos Pérez) hanno proweduto ad aggiornare gli elaborati relativi al progetto del 2010 , apportandovi le modifiche realizzate agli edifici durante le opere [14].

II raffronto tra i suddetti rilievi ha confermato due ipotesi avanzate dal gruppo di lavoro impegnato nel Progetto:

I) che, come in genere accade durante le fasi di cantiere, il progetto originario avesse subito alcune modifiche nelle geometrie e nelle dimensioni;

2) che la documentazione morfometrica alla base del progetto di rehabilitación del 2017 non raffigurasse con esattezza lo stato dei luoghi.

Per quanto concerne il primo punto, dal raffronto tra il documento del 1962 e il rilievo digitale del 2020 è emerso che gli scostamenti tra pareti omologhe (nell'ordine dei 50 centimetri, salvo in due punti specifici nei blocchi I I e 4) sono dovuti a una errata collocazione nel piano dei distinti corpi di fabbrica, le cui dimensioni e geometrie sono invece rispettate (fig. 10).

Insolita è la questione legata al secondo punto: al momento della verifica dello stato di fatto degli immobili, Atrio non era in possesso del rilievo degli anni 2000-2002 e, pertanto, ha dovuto fare affidamento sugli elaborati di progetto del 20I0. La mancanza di adeguata strumentazione, l'impossibilità di accedere a tutti vani del complesso edilizio e il fatto che tale progetto sia stato, inspiegabilmente, realizzato su una base morfometrica errata ha di fatto in parte vanificato l'intento di controllare e aggiornare i disegni (fig. I I). Di conseguenza anche il progetto del 2017 è stato redatto con un vizio di fondo legato alla imprecisione del dato geometrico-dimensionale relativo agli edifici esistenti.

Verrebbe da supporre che la causa di tali inesattezze sia da attribuire al rilievo del 20002002, sul quale verosimilmente avrebbe dovuto essere impostato il progetto del 2010; la comparazione tra il rilievo topografico e quello digitale ha invece dimostrato la sua affidabilità, rimanendo lo scostamento medio tra i due documenti al di sotto dei $15 \mathrm{~cm}$ (fig. 12). 


\section{Conclusioni}

La conservazione del patrimonio architettonico passa sovente attraverso corrette procedure di restauro che non possono che prendere avvio da una conoscenza quanto più esaustiva possibile dei manufatti. La documentazione morfometrica e cromatica, assieme a quella storica (bibliografica e archivistica) - riferita anche ai rilievi che si sono susseguiti nel tempo - costituiscono una base da cui non è possibile prescindere e che sempre più costituisce l'indispensabile premessa di ogni scelta progettuale.

I rilievi, al pari di altri documenti, sono capaci di narrare non solo le vicende di una fabbrica, ma anche di rendere manifesto, sulla base delle scelte che vengono adottate al momento di conservare un bene comune, il livello tecnologico e culturale raggiunto da una società. Grazie al progetto iQue no baje el telón! e alle iniziative che ne conseguono, gli edifici della FAT potranno essere restaurati e nuovamente utilizzati nel rispetto della funzione originaria, capace da sola di garantire la conservazione del bene attraverso le opere di ordinaria e straordinaria manutenzione necessarie ad assicurare l'uso del complesso nel tempo.

\section{Note}

[I] Tra il 1995 e il 2000 si sono verificati due eventi degni di nota: l'inclusione delle Scuole del complesso di Cubanacán nell'elenco dei 100 monumenti a rischio delWMF e la pubblicazione del libro A Revolution of Forms del prof. arch. John Loomis, che hanno contribuito ad accrescere la fama internazionale delle Scuole stesse.

[2] La necessità di fare ricorso a materiali locali portò i tre architetti a recuperare l'antica tecnica costruttiva delle volte catalane, utilizzata in Spagna sin dal XIV secolo e successivamente diffusasi in Nord America e da lì ai Caraibi e al Sud America.

[3] II primo corso, dell'Instituto Superior de Arte, oggi Universidad de las Artes, venne attivato il $1^{\circ}$ settembre 1976 ai sensi della legge n. 1307 del 29 luglio 1976.

[4] Anno in cui le Scuole furono dichiarate Monumento Nacional con la Resolución n. 03/20 I0 della Comisión Nacional de Monumentos.

[5] II progetto, inserito nella programmazione finanziaria del competente Ministero Cubano (MFP e MINCEX), è coerente con le linee strategiche negoziate tra Italia e Cuba a partire dal 2015 in ordine alla realizzazione di una nuova iniziativa della Cooperazione Italiana in appoggio al Ministerio de Cultura (MINCULT), che prevede il rafforzamento della Facultad de Arte Teatral dell'Universidad de las Arte de La Habana (ISA) e del ruolo che essa riveste nella società cubana. Fulcro del programma è il restauro e consolidamento della sede storica della FAT, dal quale deriveranno una serie di azioni formative e culturali tese a valorizzare il patrimonio materiale e immateriale del Paese. II Documento di Progetto è stato redatto dal prof Alessandro Merlo del DIDA sotto la guida dell'arch. Rita Gonelli dell'AICS e fatto successivamente proprio dal MINCULT che lo ha ufficialmente presentato al Governo italiano il 19 novembre del 2018.

[6] Le attività teoriche e applicative svolte nei sei corsi di capacity building (Levantamiento Digital y Modelación 3D, Técnicas y herramientas para el diagnóstico de la degradación y la inestabilidad, Teorías y métodos de restauración y consolidación, Técnicas e instrumentos para la gestión de obras de restauración y consolidación, Modelo de Información de la Construcción - BIM - aplicado al Facility Management, Valorización del patrimonio territorial) accompagnano il processo di revisione e completamento de progetto di rifunzionalizzazione della FAT (realizzato dall'impresa Atrio del Mincult) da parte del personale del DIDA.

[7] Si ringrazia l'impresa Restaura afferente all'Oficina del Historiador de La Habana (OHC) per aver messo a disposizione i proprio scanner laser all'interno del laboratorio di rilievo del corso di Aggiornamento Professionale tenuto dal prof. A. Merlo.

[8] Le unità scanner laser Leica ScanStation P40 e Z+F Imager® 5010 sono state messe a disposizione dall'impresa GeoCuba (Geodesa), mentre lo scanner laser Leica ScanStation C 10 è stato prestato dalla società Restaura; infine l'apparato Leica BLK360 Imaging LS è di proprietà del DIDA. GeoCuba ha realizzato anche il volo con il drone DJI Mavic 2 Pro necessario a documentare mediante fotogrammetria digitale le coperture della FAT.

[9] Le scansioni laser sono 4 I7, il numero di fotografie da terra è pari a 4.927I, mentre quelle scattate da drone sono a 2.031.

[I 0] Le operazioni di rilevamento, coordinate da Alessandro Merlo sono state realizzate dal CHMLab del DIDA, in particolare dagli architetti Giulia Lazzari, Francesco Frullini, Michela Notarnicola ed Elisa Luzzi. Le operazioni di restituzione, avvenute sotto la supervisione della Ph.D. Arch. Gaia Lavoratti, hanno visto impegnato, oltre al suddetto personale, anche l'arch. Alessandro Manghi.

[l I] Archivio Storico dell'OHC, Archivio Storico della Facultad de Arte de la Conservación dell'Universidad de las Artes.

[12] La documentazione in possesso del gruppo di lavoro impegnato nel progetto iQue no baje el telón! non consente a oggi di stabilire con certezza se furono o meno eseguite delle opere finalizzate alla conservazione dei manufatti prima degli interventi del 2010, come sembrerebbe invece far supporre una attenta analisi delle superfici murarie e degli intradossi delle coperture.

[I3] Per il fine del presente studio si faccia riferimento agli elaborati Planta baja e Planta alta (nome file DRA PB e DRA PA, data 03/06/2002, layout in scala 1:200, eseguita dal Departamento de Topografía, disegnatore Rodolfo Diego), privata delle quote, dei sanitari e delle proiezioni delle travi. 
[ 14$]$ Per il fine del presente studio si faccia riferimento agli elaborati Actualización del levantamiento, planta baja e Actualización del levantamiento, planta alta (plano no. A-00 I-00, data luglio 20 I7, layout in scala 1:250, eseguito da Atrio), privato delle quote e degli infissi.

\section{Riferimenti bibliografici}

Caccia Gherardini Susanna (2016). The architectural restoration and conservation handbook. Firenze: DidaPress.

Gottardi Roberto (1998). El arquitecto y su obra. Roberto Gottardi: pensamiento, obras y proyectos. Arquitectura Cuba, n. 378/1998, pp. 8-31.

Gottardi Roberto (2008). Restauración y completamiento de la Escuela Nacional de Artes Escénicas, Cubanacán, La Habana. Arquitectura Cuba, n. 380/2008, pp. 76-79.

Fiorucci Tiziana, Chiavoni Emanuela (a cura di). (2003). Gli strumenti di conoscenza per il progetto di restauro. Roma: Gangemi. Loomis John (201 I). A Revolution of Forms. New York: Princeton Architectural Press.

Musso Stefano Francesco (20 I0). Recupero e restauro degli edifici storici. Guida pratica al rilievo e alla diagnostica. Roma: EPC Libri. Paradiso Michele (a cura di). (20 I 6). Las Escuelas Nacionales de Arte de La Habana. Pasado, presente y futuro. Firenze: DidaPress.

Van Riel Silvio (20।3). Lo spreco edilizio attuale ed il problema del "riuso" dell'edilizia esistente in rapporto all'insegnamento del "Restauro" nelle facoltà di architettura europee. In Mora Alonso-Muñoyerro Susana, Rueda Márquez de la Plata Adela, Cruz Franco Pablo Alejandro (a cura di). ReUso 2013. Actas del congreso internacional sobre Documentación, Restauración y Reutilización del Patrimonio Arquitectónico. Madrid: Editorial de la Politecnica, pp. 29-36.

Autore

Alessandro Merlo, Università di Firenze, alessandro.merlo@unifi.it

Per citare questo capitolo: Merlo Alessandro (2020). iQue no baje el telón! Recupero e valorizzazione della Facultad de Arte Teatral dell'Universidad de las Artes de La HabanaliQue no baje el telón! Restoration and valorization of the Facultad de Arte Teatral of the Universidad de las Artes de La Habana. In Arena A., Arena M., Brandolino R.G., Colistra D., Ginex G., Mediati D., Nucifora S., Raffa P. (a cura di). Connettere. Un disegno per annodare e tessere. Atti del $42^{\circ}$ Convegno Internazionale dei Docenti delle Discipline della Rappresentazione/Connecting. Drawing for weaving relationships. Proceedings of the 42th International Conference of Representation Disciplines Teachers. Milano: FrancoAngeli, pp. 658-679. 


\title{
¡Que no baje el telón! Restoration and Valorization of the Facultad de Arte Teatral of the Universidad de las Artes de La Habana
}

\author{
Alessandro Merlo
}

Abstract

The Art Schools of Cubanacán in Havana, today Universidad de las Artes (ISA), represent Fidel Castro and Ernesto Che Guevara's first great post-Revolutionary project in the sector of education. The five initial Schools (music, dance, ballet, drama and theatre, and fine arts), in addition to being well known to the scientific community for the quality of the teaching, characterized by innovative methods of creative experimentation, are renowned for having as their original premises buildings of extraordinary architectural and landscape value which were built within the great park of the ex-Country Club.

As decades went by, and for reasons which lie outside the scope of this contribution, three of these buildings (music, ballet and theatre) were progressively abandoned and are now in a state of deplorable decay.

Thanks to the interest of the Italian government, the international cooperation project denominated iQue no baje el telón!, was launched in September of 2019 . Its purpose is the architectural and functional restoration of the original premises of the Facultad de Arte Teatral (FAT), designed by the architect Roberto Gottardi in the early Sixties; this will hopefully mark the beginning of a sustainable and participated process aimed at the revalorization of the entire complex of the ISA (national monument since $2010)$ [I]. In the work programme the morphometric and chromatic documentation of the FAT plays a key role, since it constitutes the necessary premise of the project for the restoration, conservation and management of the asset.

\section{Keywords}

Facultad de Arte Teatral de La Habana, Universidad de las Artes (ISA), cultural heritage, international cooperation, digital survey.

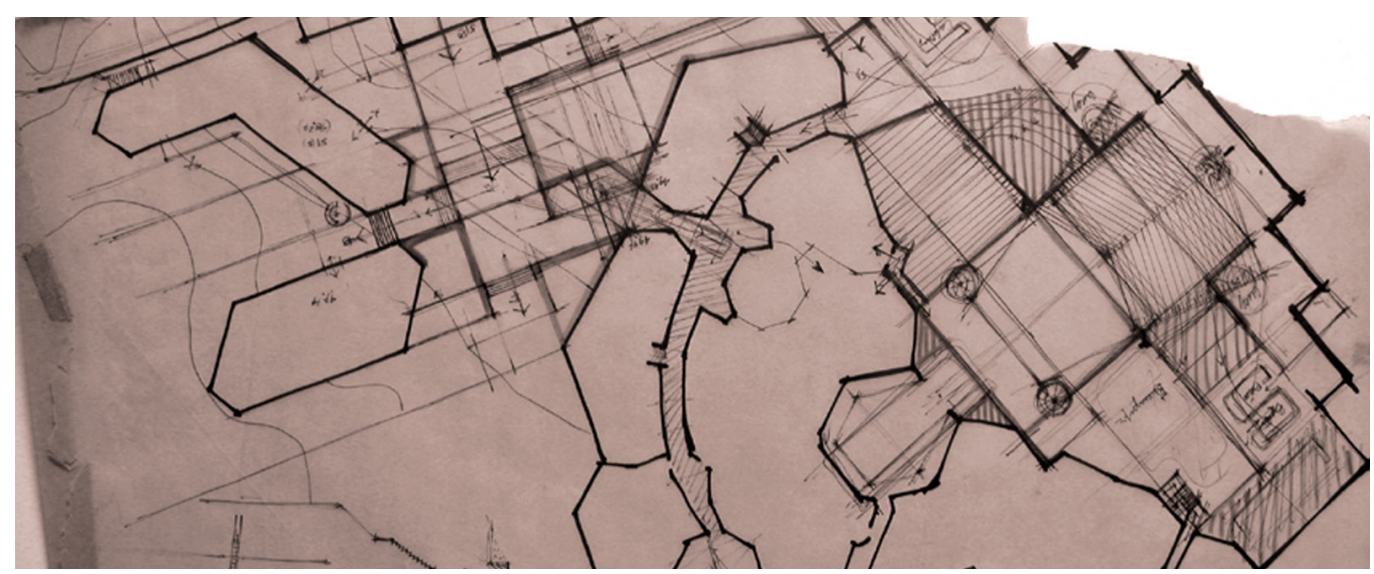




\section{From the Escuela Nacional de Artes to the Universidad de las Artes}

Five schools were built between 1960 and 1965 (covering a total of 5I,000 $\mathrm{m}^{2}$ ) inside the park of the ex-Country Club de la Habana $\left(560,000 \mathrm{~m}^{2}\right.$ between the valley floor of the Quibú river and the adjacent elevations) which, from exclusive enclave of the Cuban élite, became a space where young people of sectors of society could learn the rudiments of the Arts (fig. I).

The project was entrusted to the Cuban architect Ricardo Porro Hidalgo and to the Italian architects Roberto Gottardi and Vittorio Garatti, who were able to operate without budget limits. There were two main objectives: to integrate the buildings into the natural context of the Cubanacán (from the toponym of the area) in accordance with the Rogers' teachings, and to use nationally produced materials, in particular bricks, with the purpose of reducing the importation of steel and cement, which were expensive as a result of the United States embargo [2].

In this way, Porro Hidalgo completed the School of Fine Arts and the School of Dance, Garatti the School of Ballet and the School of Music, and Gottardi the School of Drama and Theatre (fig. 2). The design phases were, perhaps inadvertently,'participated', since technicians, labourers, professors, students and citizens, encouraged by a unique cultural context, took part in the creative process.

The buildings of the Escuela Nacional de Artes were inaugurated in 1965 (the ENA had been founded in 1962), although some parts of the architectural complex had not been completed due to lack of funding which resulted from the events related to the Cuban Missile Crisis. The School of Dance, as well as the School of Ballet, although completed, were never used for those purposes, whereas the Schools of Music, Drama and Theatre, and Fine Arts had not been completed in more than $50 \%$. The organization of educational activities had to therefore adapt to what had been built, although designed to serve different functions. During the following decade the teaching of the arts was partially reformed and, in parallel to the pre-university level managed by the ENA, the first university courses began under the authority of the ISA (Instituto Superior de Arte, today Universidad de las Artes) [3].

The Universidad de las Artes, which houses the Faculties of Música, Arte Danzario, Arte Teatral, Artes Visuales, Artes de la Conservación del Patrimonio Cultural y Restauración and Arte de los Medios de Comunicación Audiovisual, is a unique case in the country since it includes six different academic programmes in a single campus.

With the passage of time the environmental conditions, the overflowing of the Quibú river, which passes through the area, the building materials used, and the scarce maintenance or lack of it, all contributed to the decay of the buildings, making some of them unfit to be used.

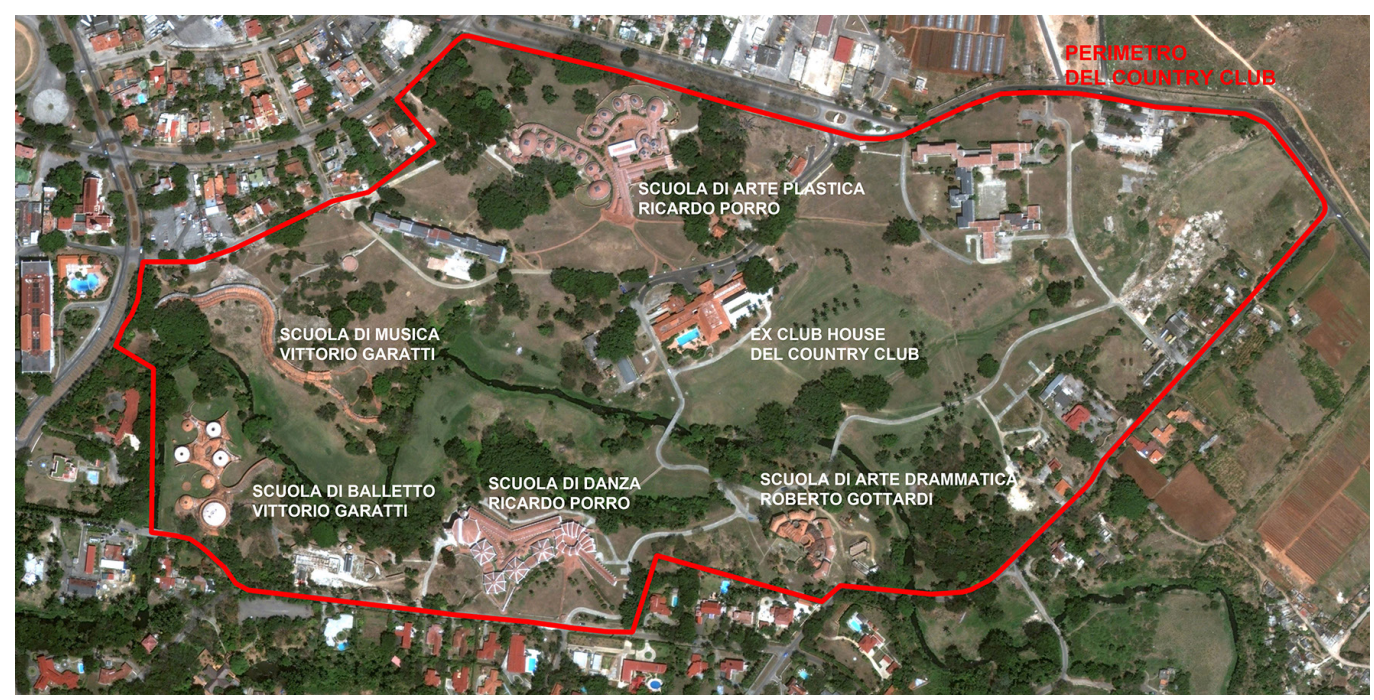




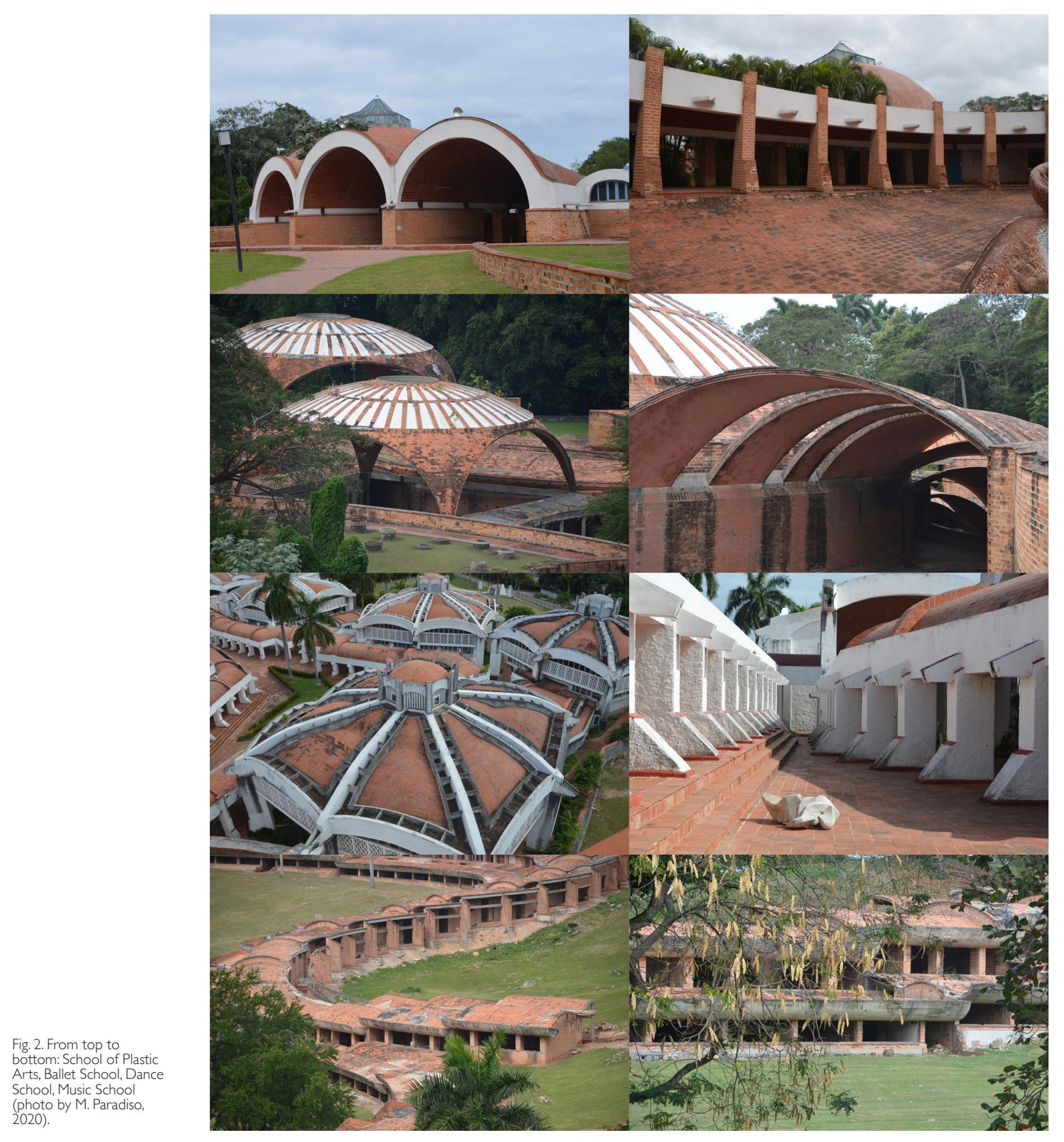


At the beginning of the 2 I st century the Cuban government addressed for the first time the problem of the restoration and completion of the buildings of the ISA, and the decision was taken to fund the works for the restoration of the complex. The Centre for Investments of the Ministerio de Cultura de la República de Cuba (MINCULT), coordinated by the Council of State, with the task of structuring the intervention programme as soon as possible, was created for this purpose. Porro Hidalgo, Gottardi and Garatti were entrusted with the project, although the actual works were led by government technicians. Starting in 1999, studies were undertaken to assess the decay of the buildings and to determine their new functional requirements; work on Porro's schools began in 2000, under the direction of the architect Universo García Lorenzo (head architect of the company Emproy-2, which is part of the Ministry of Construction MICONS), and was concluded in 2010 [4].

In early 2007, García Lorenzo presented, together with Gottardi, a first proposal for the intervention on the Escuela de Teatro; it consisted in restoring the existing built parts and in building the missing ones in accordance with the original project, as well as including expansions intended to better respond to the changes in educational needs (fig. 3). The subsequent diagnostic phases highlighted a situation of advanced decay, especially concerning sections of elevated masonry and the Catalan vaults. Work began three years later but was soon stopped due to a lack of funding.

On October 29, 2015, during an official visit to Cuba by the then President of the Council of Ministers of the Italian Republic, Matteo Renzi, the bases were set for a new project for the restoration of the Schools of Art. Having determined the FAT as the most adequate structure to begin with, the then Minister of Culture of the Republic of Cuba made a formal request of funds to Italy through the Italian office for International Development Cooperation. After three years of intense awareness-related activities, aimed at activating transverse coordination mechanisms among all the players interested in the project, on February I5, 2019, the Cuba-Italy Inter-Government Agreement was signed, which gave the go-ahead to the Project iQue no baje el telón! Conservación, Gestión y Puesta en Valor de la Facultad de Arte Teatral del ISA: Rehabilitación y Difusión, Capacitación y Monitoreo.

Fig. 3. Faculty of Theater, 2010 , design with existing blocks highlighted (Gottardi Archive, file reference: Progetto_2010/BloquesP TE_ParteExistente.pdf).

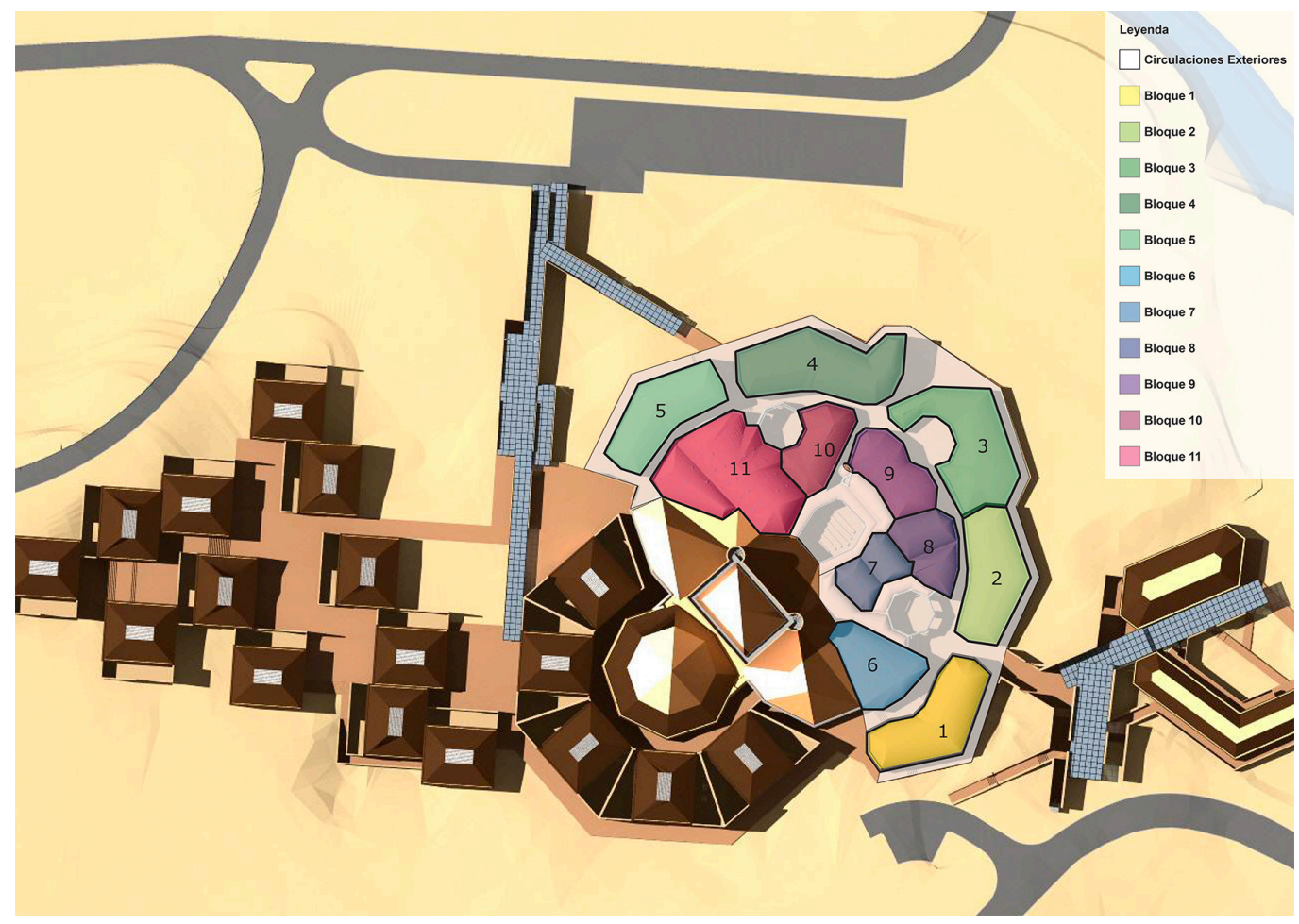




\section{The international cooperation project ¡Que no baje el telón!}

The international cooperation project [5], presented to the Agency for Cooperation and Development (AICS) of the Italian Republic by MINCULT, has as its main partners the Department of Architecture (DIDA) of the University of Florence and ISA. The main objective is that of strengthening the Facultad de Arte Teatral through three separate actions: reactivate its original premises, update the academic programmes and expand its international dimension. Given the complexity of the said actions, the Project was divided into two parts: part A (Rehabilitación y Difusión) has as its specific aim the restoration, consolidation and re-functionalization of the original premises of the FAT, as well as the diffusion of the results obtained; part B (Capacitación y Monitoreo) is aimed at capacity building for all the individuals who operate in the fields of documentation, conservation, management and valorization of the cultural heritage -in particular of the material heritage of the architectures of the ISA and of the Municipio Playa, and of the intangible heritage of the theatre arts- and the monitoring of all interventions contemplated in the Document of the Project, with the purpose of ensuring its correct execution.

The first component will not only permit the conservation and safeguarding of a cultural asset of unquestionable historical and architectural value, known and considered as such at the international level, but also to enhance and increase the educational activities of the Faculty. Once the building will be fully operative, it will be in fact possible to activate new initiatives aimed at generating awareness and to bring art and culture to the local communities, to develop projects together with other national academic contexts and to launch new collaborations at the international level.

The second component intends instead to fill some specific gaps concerning the digital survey, restoration and consolidation of the monumental buildings, through the activation of Professional Refresher Courses [6] addressed to the personnel of the Ministries that are involved in the conservation of the architectural heritage and to the professionals and

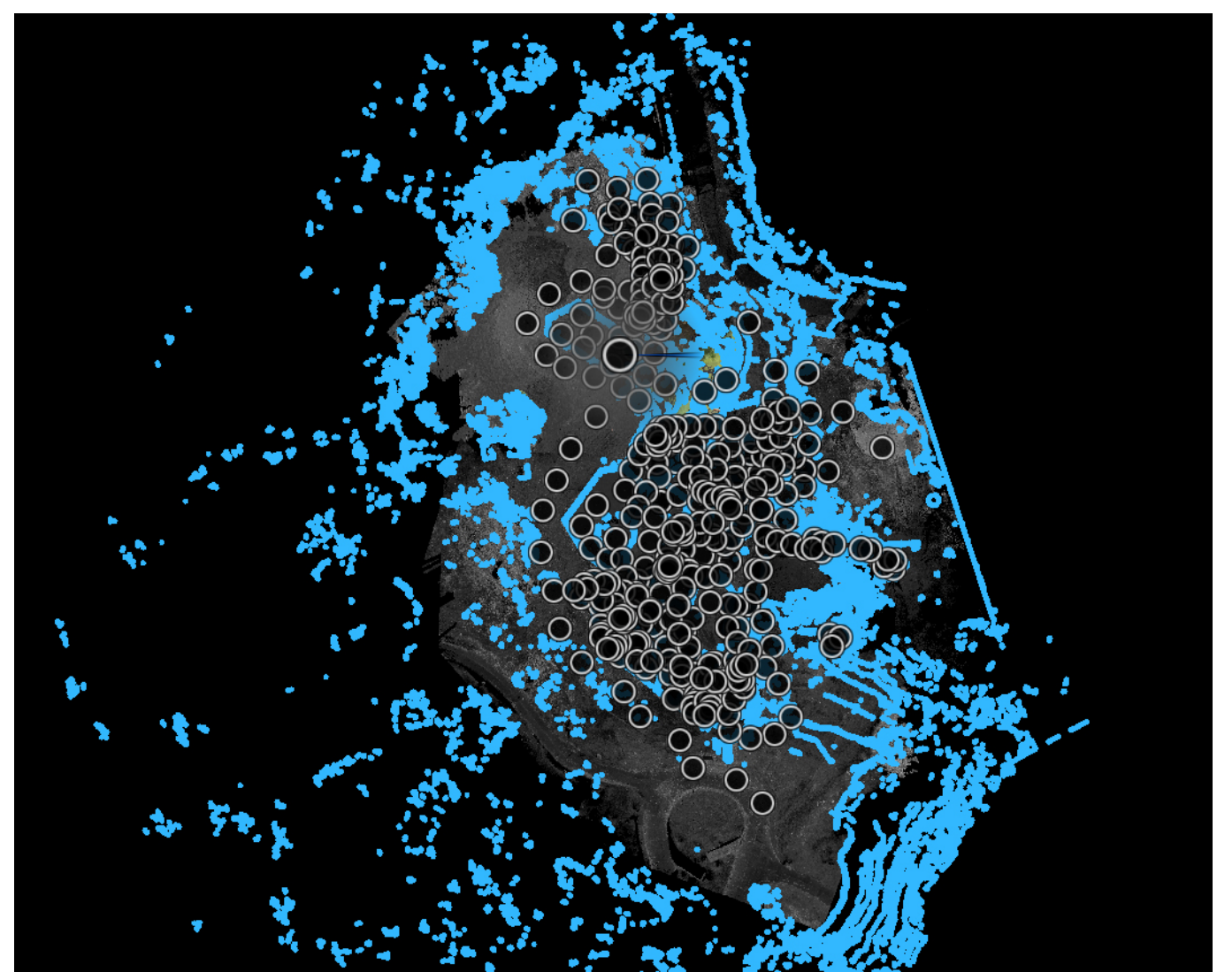




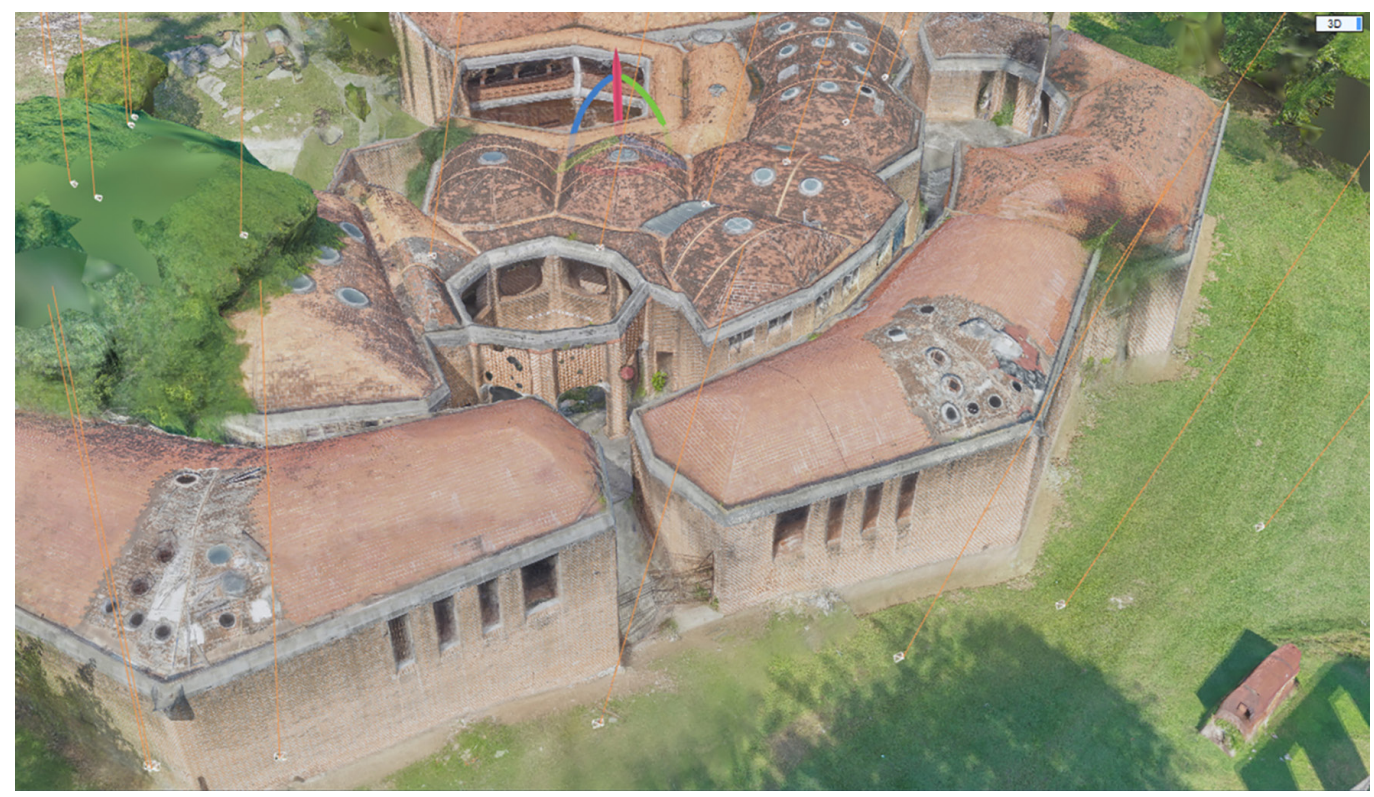

workers in the construction sector, as well as to the students of ISA and of the Faculties of Engineering and Architecture present throughout the country. In parallel to those courses, which contribute to the creation of a common knowledge base among the local and Italian personnel, DIDA has activated an action of continuous monitoring of the design and building processes, whose purpose is to ensure the concrete realization, to the highest standard, of the works in question.

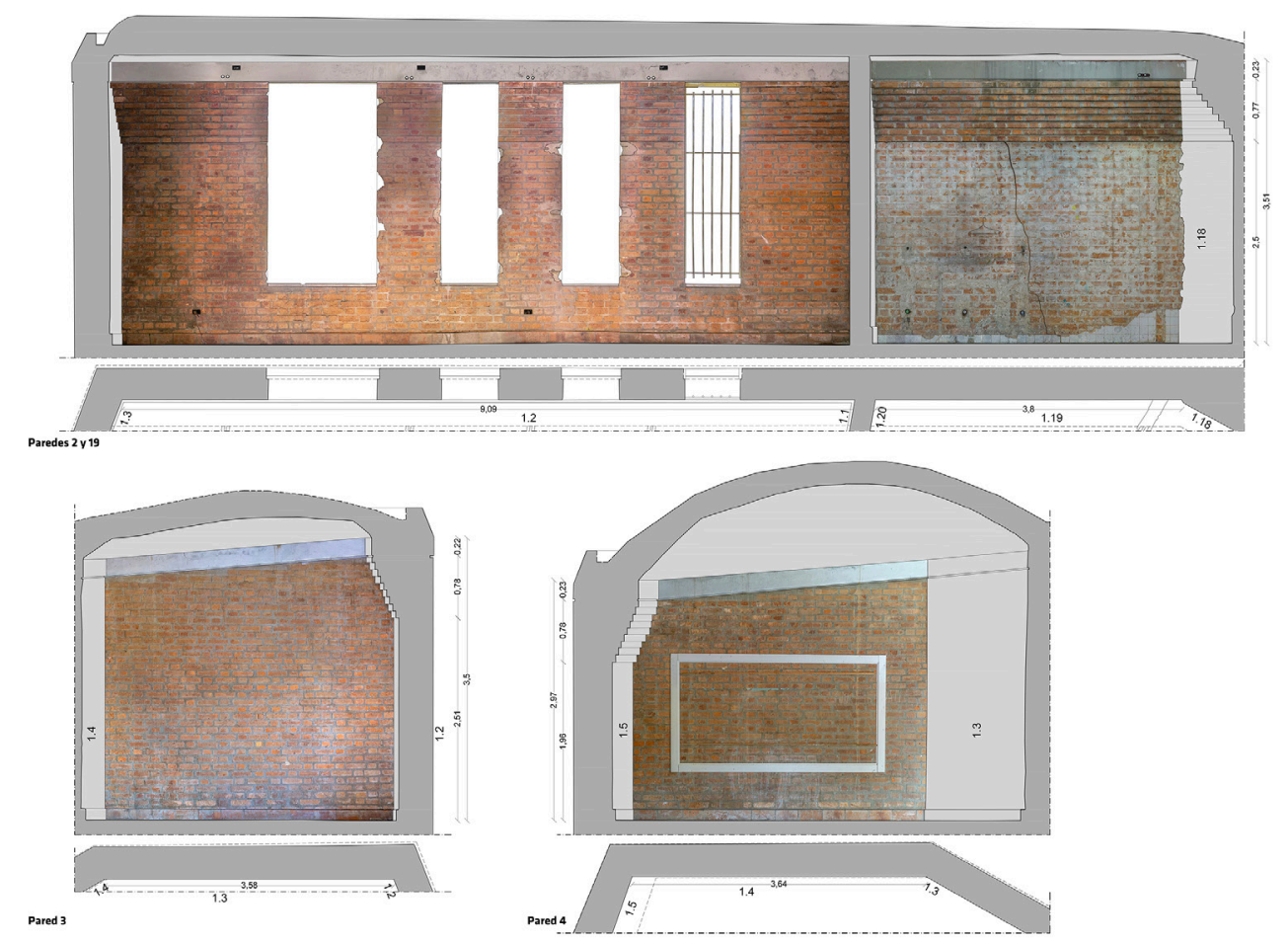


Fig. 7. Design plan, Arch. R. Gottard, 1962 (Oficin del Historiador de $L$

Habana Archive, file

reference: AHC-4549. II. Escuela de Arte Dramatico.pdf).

Fig. 8. Processing of the surveys of 2000-2002,

2010,2017 and 2020 (A. Merlo).
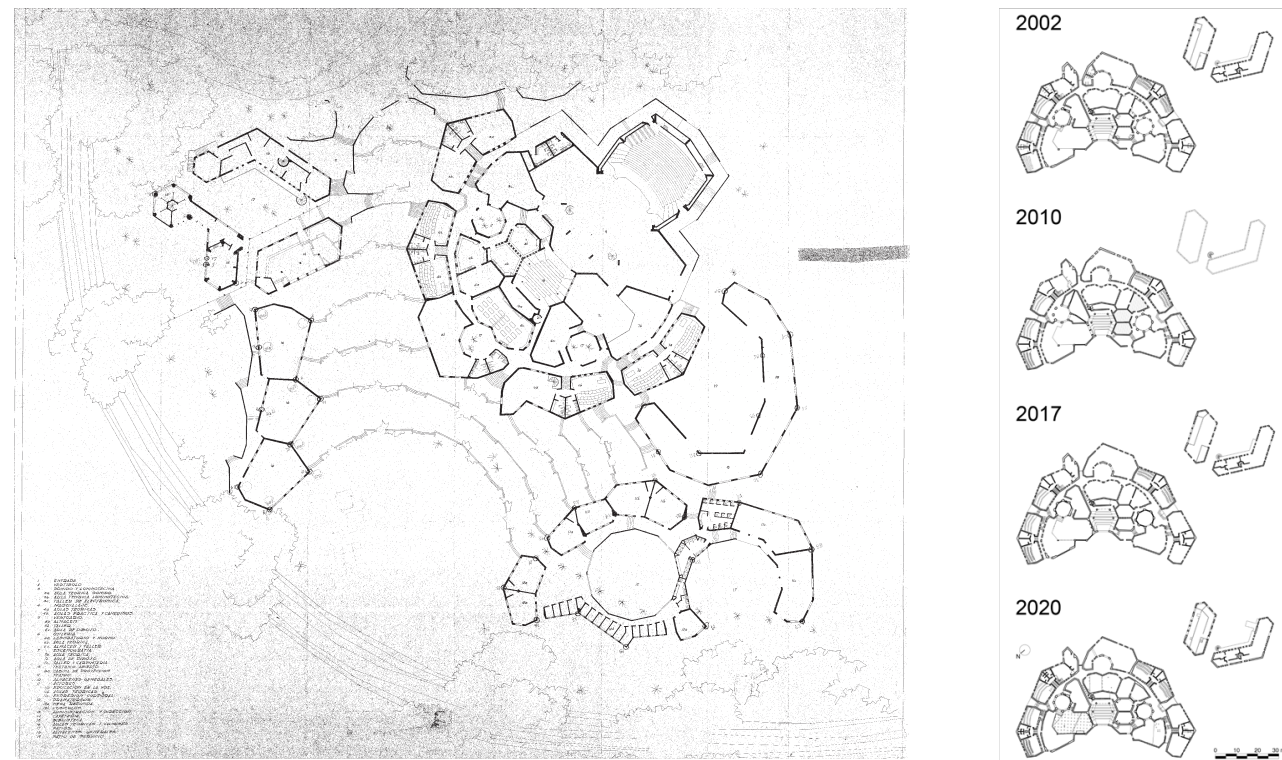

\section{Morphometric and chromatic documentation of the FAT}

The survey of the building was undertaken simultaneously with the first Professional Refresher Course [7] Levantamiento digital y modelación 3D, offered by the University of Florence and which took place between October I 4 and November Ist,2019, at the ISA. The digital documentation operations were carried out using four laser scanner units (Leica ScanStation P40, Leica ScanStation CI0, Z+F Imager ${ }^{\circledR}$ 50 I0, Leica BLK360 Imaging LS), for the morphometric aspects, and five photographic cameras (four Sony Alpha 6000 cameras with a Sony E PZ I8-105mm lens for land shots and a Hasselblad LID-20c for the aerial drone photographs) for the chromatic survey [8]. The raw data, which was processed through
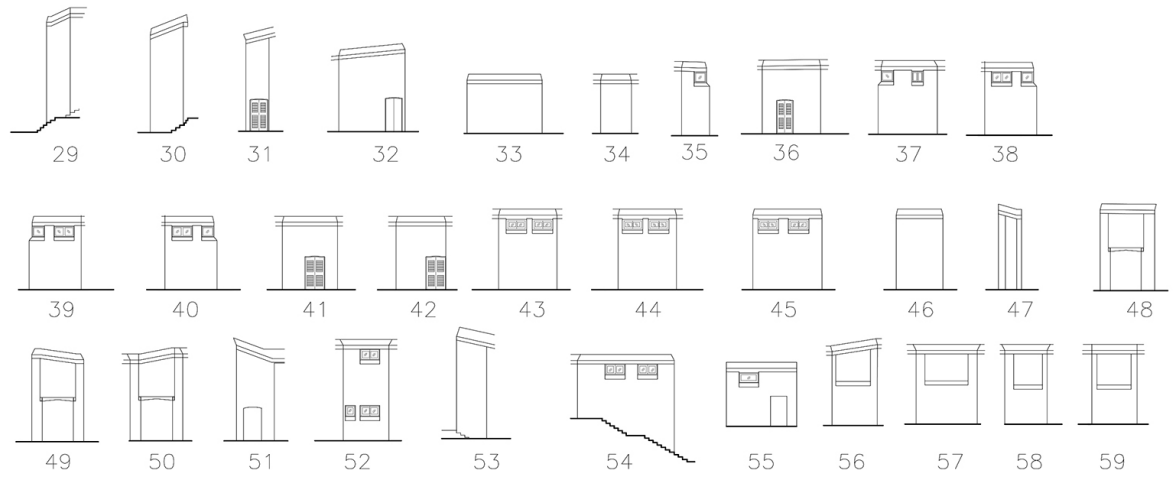
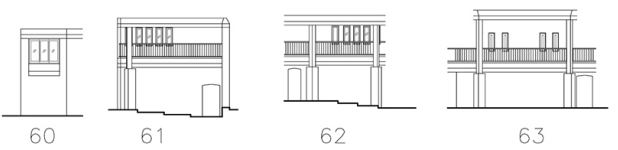

63

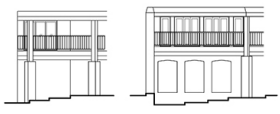

64

65
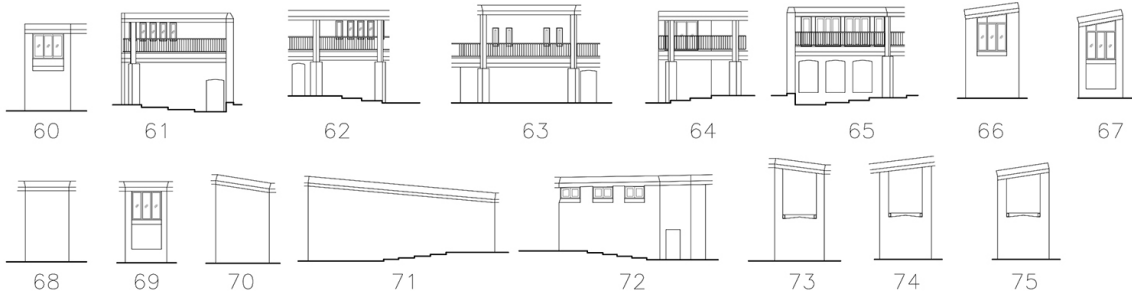
Fig. 10. Comparison

between the 1962 design and the 2020 survey in

Fig. 1 I. Comparison

between the 2020 survey survey in red (A. Merlo).

Fig. 12. Comparison

between the 2020 survey

in green and the 2000

2002 survey in blue (A.
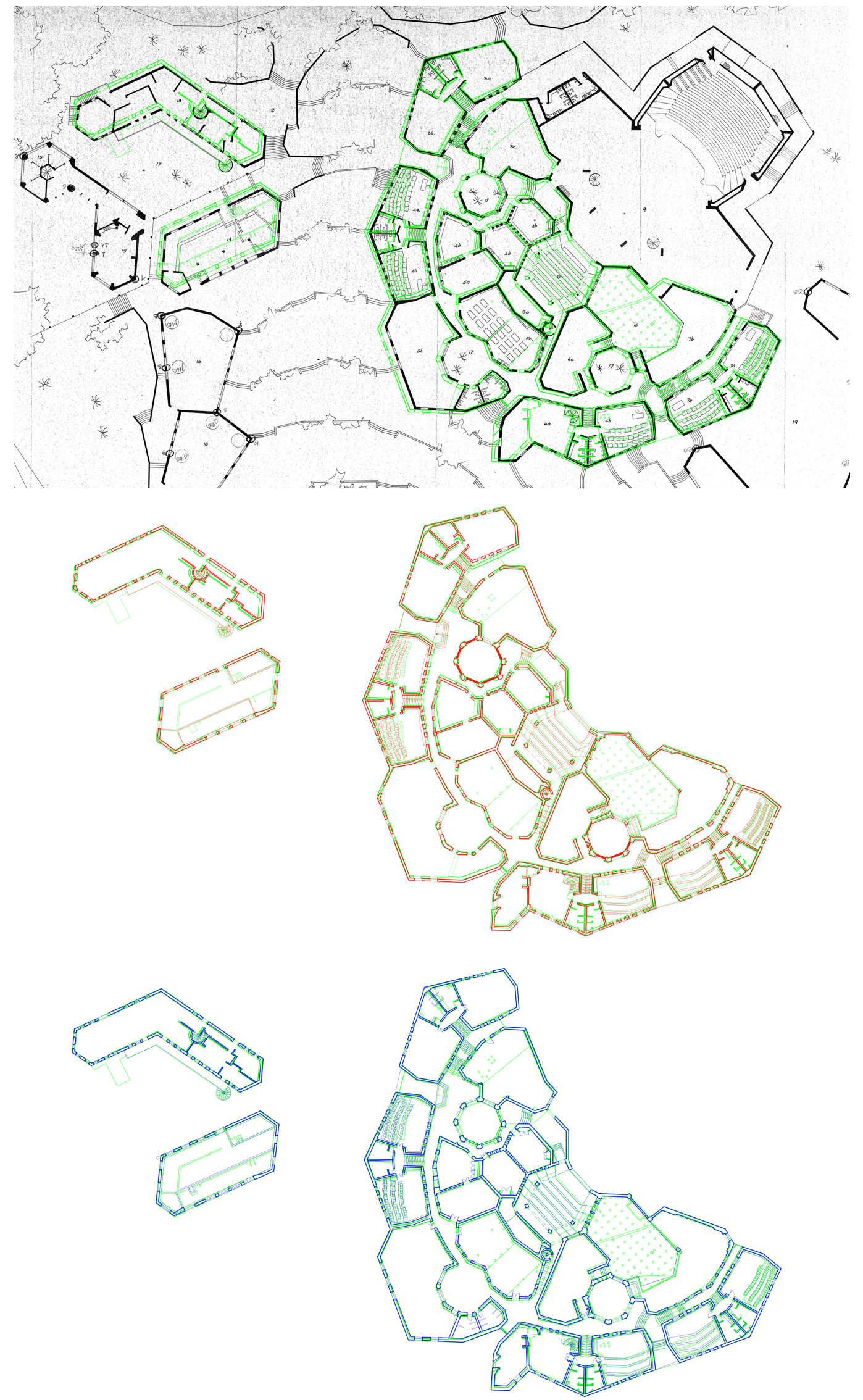
specialized software (Autocad Recap, Agisoft MetashapePro and Capturing Reality Reality Capture), permitted the extrapolation of the information into a single point cloud 3D model (247| $\times 10^{6}$ points - fig. 4) [9] and the textures of the apparent colours in the case of walls, roofs and pavings (fig. 5) [10].

From the 3D model the plans and sections of the whole complex were inferred, used initially in order to verify the accuracy of the previous surveys and to complete them whenever necessary. Photoplans at a scale of $1: 20$ (fig. 6) regarding the 14 buildings of which the FAT is composed, allowed the representation, with an adequate degree of detail, of the pathologies involving the materials and structures (topic of the second course).

Of particular interest, in this initial phase of the project, was the comparative study between the graphic material which presented the architectural project of $1962[\mathrm{II}]$, the surveys undertaken between 2000 and 2002, as well as in 2017, in view of the two main restoration interventions [12] and, finally, the digital survey of 2020.

The one from 1962 (fig. 7) shows the horizontal section of the project in an orthographic projection, carried out at different elevations in reference to the last planking level of each block (sections I, 2, 3, 7, 8, 9 and 10 present a single level, sections 4, 5, 6 have two and block II is a double volume partially subdivided by an intermediate floor). Given the peculiarity of this graphic document, for the surveys of 2000-2002, 2017 and 2020 it was necessary to draft, ex novo, an analogous version which, with the availability of the CAD images, was completed in a short time and with a margin of error that is close to zero (fig. 8).

The survey undertaken in the early 2 I st century, which resulted from a comprehensive topographic campaign carried out by the Ministerio de la Construcción (MICONS) through the Departamento de Topografía (Jefe de Departamento Miguel M. De Ayala), represents the FAT in detail by way of 3 plans, 32 sections and 75 perspective drawings, at a scale of |:50 to |:500 (fig. 9) [13].

In 2017, once the project for the rehabilitación had been entrusted to the company Atrio of MINCULT, the technicians in charge (Proyectista Principal Architect Isabel Marilyn Mederos Pérez) updated the graphic documents regarding the project of 2010 , including the modifications made to the buildings during the intervention [I 4].

The comparison between the said surveys confirmed two hypotheses presented by the work group involved in the project:

I) that, as it generally occurs during the worksite stages, the original project had suffered some modifications in terms of geometry and dimensions;

2) that the morphometric documentation at the basis of the 2017 project of rehabilitación did not accurately represent the actual state of the places in question.

In the case of the first point, from the comparison between the document of 1962 and the digital survey of 2020 it appears that the variance between analogous walls (approximately 50 centimeters, except in two specific points in blocks II and I4) is derived from the incorrect placing on the plan of various structures, whose dimensions and geometric aspects are respected instead (fig. 10).

The question linked to the second point is unusual: at the moment of verifying the actual state of the buildings, Atrio did not have access to the surveys of the years 2000-2002 and therefore had to rely on the graphic documents pertaining to the project of 2010 . The lack of adequate instruments, the impossibility of accessing all the rooms of the building complex and the fact that the project had been inexplicably carried out on an incorrect morphometric basis, in fact nullified any attempt to check and update the drawings (fig. I I). As a consequence, also the project of 2017 was drafted with a fundamental flaw linked to the lack of precision in the geometric and dimensional data regarding the existing buildings. One would suppose that the cause of these errors lies in the survey of 2000-2002, on which the 2010 project had been presumably based; the comparison between the topographic and digital surveys, instead, demonstrated its trustworthiness, since the average variance between the two documents is under $15 \mathrm{cms}$ (fig. I2). 


\section{Conclusions}

The conservation of the architectural heritage often depends on correct restoration procedures which must be based on a fully comprehensive knowledge and understanding of the buildings. The morphometric and chromatic documentation, together with the historical documentation (bibliographic and archival) -also regarding the surveys taken from time to time- constitute an absolutely necessary basis which is also increasingly considered as an essential premise of every project-related decision.

The surveys, like other documents, are capable not only of narrating the events surrounding a building, but also of manifesting, on the basis of the choices made at the moment of preserving a common asset, the technological and cultural level reached by a society.

Thanks to the project ¡Que no baje el telón!, and to the initiatives resulting from it, the buildings of the FAT may be restored and used once again in full respect of their original function, capable in itself of ensuring the conservation of the asset by means of the ordinary and extraordinary maintenance works necessary to guarantee the use of the complex through time.

\section{Notes}

[I] Two significant events took place between 1995 and 2000: the inclusion by the WMF of the Schools of the Cubanacán complex in the list of 100 monuments at risk, and the publication of the book $A$ Revolution of Forms by the professor and architect John Loomis, both of which contributed to increase the international renown of the Schools in question.

[2] The need to use local materials led the three architects to avail themselves of the old building technique of the Catalan vaults, that had been in use in Spain since the I 4th century and which later became widespread in North America and from there throughout the Caribbean and South America.

[3] The first course of the Instituto Superior de Arte, today Universidad de las Artes, began on September 1 st, 1976, in accordance with Act n. 1307 of July 29, 1976.

[4] That is the year in which the Schools were declared Monumento Nacional through Resolución n. 03/20 I0 of the Comisión Nacional de Monumentos.

[5] The project, included in the financial plan of the competent Cuban Ministry (MFP and MINCEX), is coherent with the strategic guidelines agreed upon by Italy and Cuba in 20 I 5, regarding the carrying out of a new initiative of Italian Cooperation in support of the Ministerio de Cultura (MINCULT), which envisages the stabilization of the Facultad de Arte Teatral of the Universidad de las Arte de La Habana (ISA) and of the role it plays in Cuban society. The fulcrum of the programme is the restoration and consolidation of the historical headquarters of the FAT, from which will derive a series of cultural and educational actions aimed at valorizing the material and intangible heritage of the country. The Document of the Project was drafted by Professor Alessandro Merlo of DIDA under the guidance of architect Rita Gonelli of AICS and subsequently adopted by MINCULT, who officially presented it to the Italian government on November 19, 20 I 8.

[6] The theoretical and applicative activities carried out in the six capacity building courses (Levantamiento Digital y Modelación 3D, Técnicas y herramientas para el diagnóstico de la degradación y la inestabilidad, Teorías y métodos de restauración y consolidación Técnicas e instrumentos para la gestión de obras de restauración y consolidación. Modelo de Información de la Construcción - BIM - aplicado al Facility Management, Valorización del patrimonio territorial) accompany the process of revision and completion of the project of re-functionalisation of the FAT (carried out by the Atrio company, belonging to Mincult) by DIDA personnel.

[7] We thank the company Restaura, of the Oficina del Historiador de La Habana (OHC) for having made their laser scanner available to the survey laboratory of the Professional Refresher Course held by Professor A. Merlo.

[8] The laser scanner units Leica ScanStation P40 and Z+F Imager $(5010$ were made available by the company GeoCuba (Geodesa), whereas the laser scanner Leica ScanStation C I 0 was offered by the company Restaura; finally, the Leica BLK360 Imaging LS belongs to DIDA. GeoCuba also carried out the flight of the drone DJI Mavic 2 Pro, necessary in order to document through digital photogrametry the roofs of the FAT.

[9] There is a total of 417 laser scans, of 4927I land photographs and 2031 air photographs taken by the drone.

[I0] Survey operations were coordinated by Alessandro Merlo and carried out by the CHMLab of DIDA, in particular by architects Giulia Lazzari, Francesco Frullini, Michela Notarnicola and Elisa Luzzi. Drawing operations were undertaken under the supervision of architect Gaia Lavoratti, Ph.D., with the participation, in addition to the above-mentioned personnel, of architect Alessandro Manghi.

[I I] Historical Archive of the OHC, Historical Archive of the Facultad de Arte de la Conservación of the Universidad de las Artes.

[12] The documents available to the work group involved in the project iQue no baje el telón! do not permit at present to establish with certainty whether any work aimed at the conservation of the buildings was undertaken prior to the interventions of 2010, as a careful examination of the wall surfaces and intrados would seem to indicate. 
[13] For the purposes of this study please refer to the graphic documents Planta baja and Planta alta (file names DRA PB and DRA PA, dated 03/06/2002, layout in a scale of I:200, undertaken by the Departamento de Topografía, draughtsman Rodolfo Diego), which is missing the elevations, toilets and beam projections.

[14] For the purposes of this study please refer to the graphic documents Actualización del levantamiento, planta baja and Actualización del levantamiento, planta alta (plan no. A-00 I-00, dated July 20 I 7, layout in a scale of I:250, undertaken by Atrio), which is missing the elevations, doors and windows.

\section{References}

Caccia Gherardini Susanna (2016). The architectural restoration and conservation handbook. Firenze: DidaPress.

Gottardi Roberto (1998). El arquitecto y su obra. Roberto Gottardi: pensamiento, obras y proyectos. Arquitectura Cuba, n. 378/1998, pp. 8-31.

Gottardi Roberto (2008). Restauración y completamiento de la Escuela Nacional de Artes Escénicas, Cubanacán, La Habana. Arquitectura Cuba, n. 380/2008, pp. 76-79.

Fiorucci Tiziana, Chiavoni Emanuela (a cura di). (2003). Gli strumenti di conoscenza per il progetto di restauro. Roma: Gangemi. Loomis John (20 I I). A Revolution of Forms. New York: Princeton Architectural Press.

Musso Stefano Francesco (20 10). Recupero e restauro degli edifici storici. Guida pratica al rilievo e alla diagnostica. Roma: EPC Libri. Paradiso Michele (a cura di). (20 I 6). Las Escuelas Nacionales de Arte de La Habana. Pasado, presente y futuro. Firenze: DidaPress. Van Riel Silvio (2013). Lo spreco edilizio attuale ed il problema del "riuso" dell'edilizia esistente in rapporto all'insegnamento del "Restauro" nelle facoltà di architettura europee. In Mora Alonso-Muñoyerro Susana, Rueda Márquez de la Plata Adela, Cruz Franco Pablo Alejandro (a cura di). ReUso 2013. Actas del congreso internacional sobre Documentación, Restauración y Reutilización del Patrimonio Arquitectónico. Madrid: Editorial de la Politecnica, pp. 29-36.

\section{Author}

Alessandro Merlo, Università di Firenze, alessandro.merlo@unifi.it

To cite this chapter. Merlo Alessandro (2020). QQue no baje el telón! Recupero e valorizzazione della Facultad de Arte Teatral dell'Universidad de las Artes de La Habana/iQue no baje el telón! Restoration and valorization of the Facultad de Arte Teatral of the Universidad de las Artes de La Habana. In Arena A., Arena M., Brandolino R.G., Colistra D., Ginex G., Mediati D., Nucifora S., Raffa P. (a cura di). Connettere. Un disegno per annodare e tessere. Atti del $42^{\circ}$ Convegno Internazionale dei Docenti delle Discipline della Rappresentazione/Connecting. Drawing for weaving relationships. Proceedings of the 42th International Conference of Representation Disciplines Teachers. Milano: FrancoAngeli, pp. 658-679. 